3

\title{
Identifying molecular mediators of the relationship between body mass index and endometrial cancer risk: a Mendelian randomization analysis
}

Emma Hazelwood ${ }^{1,2}$, Eleanor Sanderson ${ }^{1,2}$, Vanessa Y Tan ${ }^{1,2}$, Katherine S Ruth ${ }^{3}$, Timothy M Frayling ${ }^{4}$, Niki

Dimou $^{5}$, Marc J Gunter ${ }^{5}$, Laure Dossus ${ }^{5}$, Claire Newton ${ }^{6}$, Neil Ryan ${ }^{6,7}$, Dimitri J Pournaras ${ }^{8}$, Tracy A

O'Mara $^{9}$, George Davey Smith ${ }^{1,2}$, Richard M Martin ${ }^{1,2,10}$, James Yarmolinsky ${ }^{1,2}$

${ }^{1} \mathrm{MRC}$ Integrative Epidemiology Unit, University of Bristol, Bristol, UK

${ }^{2}$ Bristol Medical School, University of Bristol, Bristol, UK

${ }^{3}$ University of Exeter Medical School, University of Exeter, Exeter, UK

${ }^{4}$ Genetics of Complex Traits, College of Medicine and Health, University of Exeter, Exeter, UK

${ }^{5}$ Nutrition and Metabolism Branch, International Agency for Research on Cancer, Lyon, France

${ }^{6}$ Department of Gynecology, St Michaels Hospital University Hospitals Bristol NHS Foundation Trust,

Bristol, UK

${ }^{7}$ The Academic Women's Health Unit, Translational Health Sciences, Bristol Medical School, University of Bristol, Bristol, UK

${ }^{8}$ Department of Upper GI and Bariatric/Metabolic Surgery, North Bristol NHS Trust, Southmead Hospital, Bristol, UK

${ }^{9}$ Department of Genetics and Computational Biology, QIMR Berghofer Medical Research Institute, Brisbane, Queensland, Australia

${ }^{10}$ National Institute for Health Research Bristol Biomedical Research Centre, University of Bristol, University Hospitals Bristol and Weston NHS Foundation Trust, Bristol, UK

\section{Corresponding author:}

NOTE: This preprint reports new research that has not been certified by peer review and should not be used to guide clinical practice. 1 
medRxiv preprint doi: https://doi.org/10.1101/2021.12.10.21267599; this version posted December 13, 2021. The copyright holder for this preprint (which was not certified by peer review) is the author/funder, who has granted medRxiv a license to display the preprint in perpetuity.

It is made available under a CC-BY-NC-ND 4.0 International license .

25

26

27

28

29

30

31

James Yarmolinsky, PhD

MRC Integrative Epidemiology Unit

Population Health Sciences

Bristol Medical School

University of Bristol

Bristol, UK

james.yarmolinsky@bristol.ac.uk 
medRxiv preprint doi: https://doi.org/10.1101/2021.12.10.21267599; this version posted December 13, 2021. The copyright holder for this preprint (which was not certified by peer review) is the author/funder, who has granted medRxiv a license to display the preprint in perpetuity.

It is made available under a CC-BY-NC-ND 4.0 International license .

32

\section{Abstract}

Background: Endometrial cancer is the most common gynaecological cancer in high-income countries. Elevated body mass index (BMI) is an established modifiable risk factor for this condition and is estimated to confer a larger effect on endometrial cancer risk than any other cancer site. However, the molecular mechanisms underpinning this association remain unclear. We used Mendelian randomization (MR) to evaluate the causal role of 14 molecular risk factors (hormonal, metabolic, and inflammatory markers) in endometrial cancer risk. We then evaluated and quantified the potential mediating role of these molecular traits in the relationship between $\mathrm{BMI}$ and endometrial cancer.

Methods and Findings: Genetic instruments to proxy 14 molecular risk factors and BMI were constructed by identifying single-nucleotide polymorphisms (SNPs) reliably associated $\left(P<5.0 \times 10^{-8}\right)$ with each respective risk factor in previous genome-wide association studies (GWAS). Summary statistics for the association of these SNPs with overall and subtype-specific endometrial cancer risk $(12,906$ cases and 108,979 controls) were obtained from a GWAS meta-analysis of the Endometrial Cancer Association Consortium (ECAC), Epidemiology of Endometrial Cancer Consortium (E2C2), and UK Biobank. SNPs were combined into multi-allelic models and odds ratios (ORs) and 95\% confidence intervals $(95 \% \mathrm{Cls})$ were generated using inverse-variance weighted random-effects models. The mediating roles of the molecular risk factors in the relationship between $\mathrm{BMI}$ and endometrial cancer were then estimated using multivariable MR. In MR analyses, there was strong evidence that BMI (OR per SD increase: $1.88,95 \% \mathrm{Cl}: 1.69$ to $2.09, P=3.87 \times 10^{-31}$ ), total testosterone (OR per inverse normal transformed $\mathrm{nmol} / \mathrm{L}$ increase: $1.64,95 \% \mathrm{Cl}: 1.43$ to $1.88, P=1.71 \times 10^{-12}$ ), bioavailable testosterone (OR per inverse normal transformed $\mathrm{nmol} / \mathrm{L}$ increase: $1.46,95 \% \mathrm{Cl}: 1.29$ to $1.65, P=3.48 \times 10^{-9}$ ), fasting insulin (OR per natural log transformed pmol/L increase: $3.93,95 \% \mathrm{Cl}: 2.29$ to $6.74, P=7.18 \times 10^{-7}$ ) and sex hormone-binding globulin (SHBG, OR per inverse normal transformed nmol/L increase: $0.71,95 \% \mathrm{Cl}$ : 
medRxiv preprint doi: https://doi.org/10.1101/2021.12.10.21267599; this version posted December 13, 2021. The copyright holder for this preprint (which was not certified by peer review) is the author/funder, who has granted medRxiv a license to display the preprint in perpetuity. It is made available under a CC-BY-NC-ND 4.0 International license.

550.59 to $\left.0.85, P=2.07 \times 10^{-4}\right)$ had a causal effect on endometrial cancer risk. Additionally, there was 56 suggestive evidence that total serum cholesterol (OR per $\mathrm{mg} / \mathrm{dL}$ increase: $0.90,95 \% \mathrm{Cl}: 0.81$ to $1.00, P=$ $574.01 \times 10^{-2}$ ) had an effect on endometrial cancer risk. In mediation analysis using multivariable MR, we 58 found evidence for a mediating role of fasting insulin (19\% total effect mediated, $95 \% \mathrm{Cl}: 5$ to $34 \%, P=$ $599.17 \times 10^{-3}$ ), bioavailable testosterone ( $15 \%$ mediated, $95 \% \mathrm{Cl}: 10$ to $\left.20 \%, P=1.43 \times 10^{-8}\right)$, and SHBG $(7 \%$

60 mediated, $95 \% \mathrm{Cl}: 1$ to $12 \%, P=1.81 \times 10^{-2}$ ) in the relationship between $\mathrm{BMI}$ and endometrial cancer

61 risk. The primary limitations of this analysis include the assumption of linear relationships across

62 univariable and multivariable analyses and the restriction of analyses to individuals of European 63 ancestry.

64 Conclusions: Our comprehensive Mendelian randomization analysis provides insight into potential causal mechanisms linking BMI with endometrial cancer risk and suggests pharmacological targeting of 66 insulinemic and hormonal traits as a potential strategy for the prevention of endometrial cancer. 
medRxiv preprint doi: https://doi.org/10.1101/2021.12.10.21267599; this version posted December 13, 2021. The copyright holder for this preprint (which was not certified by peer review) is the author/funder, who has granted medRxiv a license to display the preprint in perpetuity.

It is made available under a CC-BY-NC-ND 4.0 International license .

\section{Introduction}

Endometrial cancer is the most common gynaecological cancer in high-income countries and the second most common globally [1, 2]. In 2020, there were 417,367 new cases diagnosed and 97,370 endometrial cancer-related deaths worldwide [3]. In contrast to several other cancer types where incidence rates have been declining over the past two decades, the global incidence of endometrial cancer continues to increase [4-8]. estimated to confer a larger effect on risk of this malignancy than any other cancer type [9-11]. A recent meta-analysis of 30 prospective studies reported that each $5 \mathrm{~kg} / \mathrm{m}^{2}$ increase in BMI was associated with a 54\% (95\% Cl: 47 to $61 \%$ ) higher risk of endometrial cancer [12-14]. It is estimated that excess adiposity accounts for $34 \%$ of global endometrial cancer cases, with the increasing incidence of endometrial cancer mirroring rising levels of obesity worldwide [15-17]. Lifestyle and dietary interventions encouraging maintenance of a healthy weight therefore remain cornerstones for the primary prevention of endometrial cancer [9]. Alongside weight management strategies, greater characterisation of the molecular mechanisms underpinning an effect of excess adiposity on endometrial cancer could provide a complementary approach to cancer prevention through the development of pharmacological interventions targeting these traits in high-risk groups.

Observational epidemiological studies have reported associations between several hormonal, metabolic, and inflammatory factors linked to obesity and endometrial cancer, including bioavailable testosterone, sex hormone-binding globulin (SHBG), oestradiol and fasting insulin [18-22]. However, conventional observational studies are susceptible to residual confounding (due to unmeasured or imprecisely measured confounders), reverse causation, and other forms of bias which undermine robust 
medRxiv preprint doi: https://doi.org/10.1101/2021.12.10.21267599; this version posted December 13, 2021. The copyright holder for this preprint (which was not certified by peer review) is the author/funder, who has granted medRxiv a license to display the preprint in perpetuity.

It is made available under a CC-BY-NC-ND 4.0 International license .

causal inference. Therefore, the causal nature of these risk factors, and thus their suitability as effective intervention targets for endometrial cancer prevention, remains unclear.

Mendelian randomization (MR) is an analytical approach that uses germline genetic variants as instruments ("proxies") for risk factors to evaluate the causal effects of these factors on disease outcomes in observational settings $[23,24]$. Since germline genetic variants are randomly assorted at meiosis, MR analyses should be less prone to confounding by lifestyle and environmental factors than conventional observational studies. Furthermore, since germline genetic variants are fixed at conception, MR analyses are not subject to reverse causation bias. The statistical power and precision of MR analysis can be increased by employing a "two-sample MR" framework in which summary genetic association data from two independent samples - one representing genetic variant-exposure associations and one representing genetic variant-outcome associations - are synthesised to estimate causal effects [25].

Recent MR studies have suggested potential causal relationships between circulating levels of several molecular traits, including low-density lipoprotein (LDL) cholesterol, insulin, total and bioavailable testosterone, and sex hormone-binding globulin (SHBG) and endometrial cancer risk, and have confirmed a causal role of BMI in endometrial cancer risk [17, 26-32]. However, many previously reported molecular risk factors for endometrial cancer from conventional observational studies remain untested in an MR framework, meaning the causal relevance of these factors in disease onset is unclear. Additionally, no MR studies to date have attempted to quantify the potential mediating role of these factors in the relationship between BMI and endometrial cancer risk.

Given the unclear causal relevance of previously reported molecular traits in endometrial cancer aetiology, we used a two-sample MR approach to evaluate the causal role of 14 endogenous sex hormones, metabolic traits, and inflammatory markers in endometrial cancer risk (overall and in 
medRxiv preprint doi: https://doi.org/10.1101/2021.12.10.21267599; this version posted December 13, 2021. The copyright holder for this preprint (which was not certified by peer review) is the author/funder, who has granted medRxiv a license to display the preprint in perpetuity. It is made available under a CC-BY-NC-ND 4.0 International license .

112

113 endometrioid and non-endometrioid subtypes). We then used multivariable MR to evaluate and

114 quantify the mediating role of these molecular traits in the relationship between $\mathrm{BMI}$ and endometrial

115 cancer risk. 
medRxiv preprint doi: https://doi.org/10.1101/2021.12.10.21267599; this version posted December 13, 2021. The copyright holder for this preprint (which was not certified by peer review) is the author/funder, who has granted medRxiv a license to display the preprint in perpetuity.

It is made available under a CC-BY-NC-ND 4.0 International license .

116

117

118

119

120

121

122

\section{Methods}

Our analytical strategy was as follows: first, we attempted to corroborate previous MR findings that there was evidence of a causal relationship between BMI and endometrial cancer risk (overall and by histological subtype); second, we examined evidence for a causal relationship between previously reported molecular factors and endometrial cancer risk (overall and by histological subtype); third, we evaluated the causal relationship between $\mathrm{BMI}$ and those molecular risk factors that were confirmed to influence endometrial cancer risk (overall and by histological subtype); finally, we performed a mediation analysis to quantify the proportion of the total effect of BMI on endometrial cancer risk that was mediated by each identified trait.

\section{Endometrial cancer study population}

obtained from a genome-wide association study (GWAS) of 12,906 cases (including 8,758 endometrioid and 1,230 non-endometrioid endometrial cancer cases) and up to 108,979 controls of European ancestry [31]. This meta-GWAS combined 17 previously reported studies from the Endometrial Cancer Association Consortium (ECAC), the Epidemiology of Endometrial Cancer Consortium (E2C2), and UK Biobank, with four studies contributing samples to more than one genotyping project. Participants were recruited from Australia, Belgium, Germany, Poland, Sweden, the UK, and the USA and associations were adjusted for principal components of ancestry. Genotyping was performed using one of several Illumina arrays and imputation was performed using the 1000 Genomes Phase 3 reference panel [33]. Further information on this meta-GWAS including study-specific genotyping, imputation, and quality control procedures is provided in S2 Appendix. 
medRxiv preprint doi: https://doi.org/10.1101/2021.12.10.21267599; this version posted December 13, 2021. The copyright holder for this preprint (which was not certified by peer review) is the author/funder, who has granted medRxiv a license to display the preprint in perpetuity.

It is made available under a CC-BY-NC-ND 4.0 International license .

138

Identification of previously reported molecular risk factors for endometrial cancer

We performed two pragmatic searches of the literature using PubMed. The first search identified previously published MR analyses of molecular risk factors for endometrial cancer. The second search identified narrative or systematic reviews of potential molecular mechanisms underpinning the relationship between obesity and endometrial cancer (additional information on search strategies used in literature reviews is presented in S3 Appendix). Combined, these literature reviews identified 20 unique molecular traits which could mediate the effect of BMI on endometrial cancer risk, of which 14 had suitable genetic instruments available. These traits include nine metabolic factors (low-density lipoprotein (LDL) cholesterol, high-density lipoprotein (HDL) cholesterol, total serum cholesterol, triglycerides, blood glucose, fasting insulin, insulin-like growth factor 1 (IGF-1), adiponectin, and leptin); three endogenous sex hormones or traits that regulate their bioactivity (total and bioavailable testosterone, and SHBG); and two inflammatory markers (interleukin-6 (IL-6) and C-reactive protein (CRP), measured as high-sensitivity CRP) (Fig 1) [29, 34-41]. Summary genetic association data on BMI were obtained from a GWAS of 681,275 individuals of European ancestry [42]. Additional information on participant demographics and covariates included in adjustment strategies across each GWAS are presented in $\mathbf{S 4}$ Table. All studies contributing data to these analyses had the relevant institutional review board approval from each country, in accordance with the Declaration of Helsinki, and all participants provided informed consent.

\section{Statistical analyses}


medRxiv preprint doi: https://doi.org/10.1101/2021.12.10.21267599; this version posted December 13, 2021. The copyright holder for this preprint (which was not certified by peer review) is the author/funder, who has granted medRxiv a license to display the preprint in perpetuity.

It is made available under a CC-BY-NC-ND 4.0 International license .

MR analysis can generate unbiased estimates of causal effects of risk factors on disease outcomes if the following assumptions are met: (i) the instrument strongly associates with the exposure ("relevance"), (ii) there is no confounding of the instrument-outcome relationship ("exchangeability"), and (iii) the instrument only affects the outcome through the exposure ("exclusion restriction") (Fig. 2) [43].

To construct genetic instruments for BMI and previously reported molecular risk factors, we obtained single-nucleotide polymorphisms (SNPs) reliably $\left(P<5 \times 10^{-8}\right)$ and independently $\left(r^{2}<0.001\right)$ associated with each trait. To construct a genetic instrument for leptin, we restricted genetic variants to cis-acting SNPs (i.e. in or within $\pm 100 \mathrm{~kb}$ from the gene encoding the protein). For leptin, IL-6 and CRP analyses, SNPs were permitted to be in weak linkage disequilibrium (LD) $\left(r^{2}<0.10\right)$ to maximise instrument strength. For all traits where instruments consisted of SNPs in weak LD (i.e. leptin, IL-6 and CRP), standard errors for causal estimates were inflated to account for correlation between SNPs with reference to the 1000 Genomes Phase 3 reference panel $[33,44]$.

For traits instrumented by a single SNP, the Wald ratio was used to generate effect estimates and the delta method was used to approximate standard errors [45]. For traits instrumented by two or more SNPs, inverse-variance weighted (IVW) random-effects models were used to estimate causal effects [45]. A Bonferroni correction was applied as a heuristic to account for multiple testing in MR analyses for the 15 risk factors (14 molecular traits and BMI) investigated. Results below this threshold were classified as "strong evidence" $\left(P<3.33 \times 10^{-3}(0.05 / 15\right.$ traits $\left.)\right)$, whereas results between this threshold and $P<0.05$ were classified as "suggestive evidence".

When using genetic instruments, there is potential for horizontal pleiotropy - when a genetic variant influences an outcome through a biological pathway independent to the exposure, a violation of the "exclusion restriction" criterion [46]. We evaluated the presence of horizontal pleiotropy by 
medRxiv preprint doi: https://doi.org/10.1101/2021.12.10.21267599; this version posted December 13, 2021. The copyright holder for this preprint (which was not certified by peer review) is the author/funder, who has granted medRxiv a license to display the preprint in perpetuity.

It is made available under a CC-BY-NC-ND 4.0 International license .

182

183

184

185

186

187

188

189

190

191

192

193

194

195

performing various sensitivity analyses. First, for instruments consisting of $\geq 10$ SNPs, we re-calculated causal estimates obtained from IVW models using MR-Egger regression, weighted median estimation, and weighted mode estimation (additional information on these sensitivity analyses is provided in S2 Appendix) [46-48]. Each of these models makes different assumptions regarding the nature of horizontal pleiotropy in the genetic instrument and therefore performing all three can provide complementary support to IVW models in evaluating the presence of horizontal pleiotropy. These models were not employed when instruments consisted of $<10$ SNPs because of their reduced statistical power to detect horizontal pleiotropy in these settings (additional information on these sensitivity analyses is provided in S2 Appendix). Second, we performed "leave-one-out" analyses for all findings showing strong or suggestive evidence of effects in IVW models $(P<0.05)$ for traits where instruments consisted of $\geq 10$ SNPs and findings were consistent across MR-Egger, weighted median, and weighted mode sensitivity analyses or where instruments consisted of $<10$ SNPs. This approach sequentially removes each SNP from an instrument and then re-calculates the overall effect estimate to examine robustness of findings to individual influential SNPs in IVW models.

Instruments were derived from sex-combined GWAS for all traits other than those related to endogenous sex hormones to maximise statistical power where there was limited evidence of sexspecificity of SNP associations. As a sensitivity analysis we also re-performed MR analyses using sexspecific instruments where possible. For BMI, all analyses with strong or suggestive evidence for an effect $(P<0.05)$ were repeated using genome-wide significant $\left(P<5.0 \times 10^{-8}\right)$ variants identified in female-specific analyses. Likewise, for fasting insulin and CRP analyses, the effect estimates and standard errors of SNPs used to instrument these traits were replaced with female-specific values where there was previous evidence of sex-specificity of associations (trait-specific criteria for identifying sexspecific effects are presented in S2 Appendix). Findings from sex-specific sensitivity analyses are presented in Tables S8, S17, S28-29. Finally, Steiger filtering was performed across all analyses to 
medRxiv preprint doi: https://doi.org/10.1101/2021.12.10.21267599; this version posted December 13, 2021. The copyright holder for this preprint (which was not certified by peer review) is the author/funder, who has granted medRxiv a license to display the preprint in perpetuity.

It is made available under a CC-BY-NC-ND 4.0 International license .

identify and subsequently remove any SNPS which explained more variance in the outcome than the exposure (i.e. suggesting misspecification of the causal direction between traits) [49].

Mediation analysis

For all molecular traits that were identified as being on the causal pathway between BMI and endometrial cancer risk, we used multivariable MR to generate estimates of the direct effect (i.e. the remaining effect of the exposure on the outcome when the effect of the candidate mediator on the outcome has been adjusted for) and indirect effect (i.e. the effect of the exposure on the outcome through the candidate mediator) using the product of coefficients method [50]. The proportion of the total effect of BMI on endometrial cancer risk ("proportion mediated") that was mediated by each molecular trait was calculated using these estimates. In the case of fasting insulin, due to weak instrument bias, several different approaches were employed to attempt to maximise conditional instrument strength (for further information on these analyses see S2 Appendix). Standard errors for the proportion mediated were calculated using the delta method [51]. In addition, we aimed to perform additional mediation analyses combining all mediators into a single model to examine the extent to which these mediators influenced endometrial cancer independently or via shared biological pathways (presumed relationships between BMI, fasting insulin, SHBG, bioavailable testosterone, and endometrial cancer risk are presented in Fig 3). When all putative mediators were combined into a single model with $\mathrm{BMI}$, however, there was persistent weak instrument bias. Of various alternate approaches examined to minimise this bias, the restriction of models to pairs of mediators (without inclusion of BMI) was found to generate the largest conditional F-statistics for each mediator included in the model (for further information on these analyses see S2 Appendix). 
medRxiv preprint doi: https://doi.org/10.1101/2021.12.10.21267599; this version posted December 13, 2021. The copyright holder for this preprint (which was not certified by peer review) is the author/funder, who has granted medRxiv a license to display the preprint in perpetuity.

It is made available under a CC-BY-NC-ND 4.0 International license .

228

Sample overlap sensitivity analyses

There was moderate sample overlap (52.2-62.4\%) across some analyses which can bias MR estimates toward the confounded observational estimate in the presence of weak instrument bias [52] (S5 Table). This bias can be inflated by "Winner's curse", in which weights for genetic instruments are derived from discovery samples that overlap with outcome samples. Though instruments in this analysis were constructed from genome-wide significant variants $\left(P<5.0 \times 10^{-8}\right)$ which should minimise the possibility of weak instrument bias, we performed the following sensitivity analyses to evaluate whether our findings could be influenced by sample overlap: i) for analyses examining the effect of blood glucose on endometrial cancer risk, we re-performed MR analyses using alternate GWAS data for this trait where there was no sample overlap $[53,54]$; ii) for analyses examining the effect of BMI on total testosterone, bioavailable testosterone, SHBG and endometrial cancer, we re-performed MR analyses using alternate GWAS data for BMI where there was no sample overlap [55]; and iii) for analyses examining the effect of total testosterone, bioavailable testosterone, SHBG and IGF-1 on endometrial cancer (where suitable alternate GWAS data were not available), we re-constructed instruments for sex hormones using more conservative $P$-value thresholds $\left(P<5.0 \times 10^{-9}, P<5.0 \times 10^{-10}\right)$ to minimise the potential for inclusion of weak instruments into analyses and then re-performed MR analyses. Similarly, in mediation analysis, due to the presence of sample overlap and possible influence of Winner's curse, for any trait with sample overlap in the same multivariable MR model the analysis was repeated with a more stringent $P$ value $\left(P<5.0 \times 10^{-9}\right)$ used for instrument construction.

All statistical analyses were performed using R (Vienna, Austria) version 4.0.2. Additional information on statistical packages used across various analyses is presented in S2 Appendix. 
medRxiv preprint doi: https://doi.org/10.1101/2021.12.10.21267599; this version posted December 13, 2021. The copyright holder for this preprint (which was not certified by peer review) is the author/funder, who has granted medRxiv a license to display the preprint in perpetuity.

It is made available under a CC-BY-NC-ND 4.0 International license .

250

251

\section{Results}

\section{Evaluating the effect of BMI on endometrial cancer risk}

In MR analyses, there was strong evidence for an effect of BMI on risk of overall endometrial cancer (odds ratio (OR) per SD $\left(4.7 \mathrm{~kg} / \mathrm{m}^{2}\right)$ increase in BMI: $1.88,95 \%$ confidence interval $(\mathrm{Cl}): 1.69$ to 2.09, $P=3.87 \times 10^{-31}$ ) (Fig 4, Table 2). This finding was consistent across sensitivity analyses examining evidence of horizontal pleiotropy, including MR-Egger, weighted median, and weighted mode models, in analyses using a female-specific BMI instrument, in analyses exploring potential Winner's curse bias in instrument construction, and in the leave-one-out analysis (S7 Figure, S8 Table, S9 Table).

In subtype-stratified analyses, there was evidence to support an effect of BMI on risk of both endometrioid (OR per SD $\left(4.7 \mathrm{~kg} / \mathrm{m}^{2}\right)$ increase in $\mathrm{BMI}: 1.89,95 \% \mathrm{Cl}: 1.65$ to $2.16, P=1.67 \times 10^{-20}$ ) and non-endometrioid endometrial cancer (OR per SD $\left(4.7 \mathrm{~kg} / \mathrm{m}^{2}\right)$ increase in $\mathrm{BMI}: 1.67,95 \% \mathrm{Cl}: 1.19$ to 2.35 , $P=3.03 \times 10^{-3}$ ) (Fig 4, Table 2). These findings were robust to sensitivity analyses for endometrioid endometrial cancer; however, findings were less consistent for non-endometrioid endometrial cancer in sensitivity analyses using female-specific BMI instruments (S10-11 Figure, S8-9 Table). Therefore, only overall and endometrioid endometrial cancer were included in follow-up analyses.

\section{Evaluating the effect of previously reported molecular risk factors on endometrial cancer risk}

When examining the effect of previously reported molecular risk factors on overall endometrial cancer risk, there was strong evidence for an effect of total testosterone (OR per increase in inversenormal transformed (INT) nmol/L total testosterone: $1.64,95 \% \mathrm{Cl}: 1.43$ to $1.88, P=1.71 \times 10^{-12}$ ), bioavailable testosterone (OR per increase in INT nmol/L bioavailable testosterone: $1.46,95 \% \mathrm{Cl}: 1.29$ to 1.65, $P=3.48 \times 10^{-9}$ ), fasting insulin (OR per increase in natural log transformed pmol/L fasting insulin 
medRxiv preprint doi: https://doi.org/10.1101/2021.12.10.21267599; this version posted December 13, 2021. The copyright holder for this preprint (which was not certified by peer review) is the author/funder, who has granted medRxiv a license to display the preprint in perpetuity.

It is made available under a CC-BY-NC-ND 4.0 International license .

272

273

274

275

276

3.93, $95 \% \mathrm{Cl}: 2.29$ to $6.74, P=7.18 \times 10^{-7}$ ), and SHBG (OR per increase in INT nmol/L SHBG $0.71,95 \% \mathrm{Cl}$ : 0.59 to $0.85, P=2.07 \times 10^{-4}$ ) on endometrial cancer risk (Fig 5; Table 3). In addition, there was suggestive evidence for an effect of total serum cholesterol (OR per increase in SD $(41.7 \mathrm{mg} / \mathrm{dL}$ ) total serum cholesterol $0.90,95 \% \mathrm{Cl}: 0.81$ to $1.00, P=4.01 \times 10^{-2}$ ) on overall endometrial cancer risk. These findings were consistent across sensitivity analyses (S12-S16 Figure, S17 Table, S8-S9 Table).

In subtype-stratified analyses, there was strong evidence to support an effect of total testosterone (OR per increase in INT nmol/L total testosterone: $1.60,95 \% \mathrm{Cl}: 1.36$ to $1.87, P=8.70 \times 10^{-}$ ${ }^{9}$ ), bioavailable testosterone (OR per increase in INT nmol/L bioavailable testosterone: $1.46,95 \% \mathrm{Cl}: 1.29$ to $1.65, P=3.48 \times 10^{-9}$ ), fasting insulin (OR per increase in natural log transformed $\mathrm{pmol} / \mathrm{L}$ fasting insulin: 4.64, 95\% Cl: 2.30 to $9.36, P=1.84 \times 10^{-5}$ ), and SHBG (OR per increase in INT nmol/L SHBG: $0.65,95 \% \mathrm{Cl}$ : 0.54 to $0.80, P=3.31 \times 10^{-5}$ ) on endometrioid endometrial cancer risk (Fig 5; Table 3). Findings were consistent across all sensitivity analyses (S19-S22 Figure, S9 Table, S17 Table).

Evaluating the effect of $B M I$ on previously reported molecular risk factors

When examining the effect of BMI on molecular traits confirmed to have a causal effect on endometrial cancer (either overall or endometrioid subtype), there was evidence for an effect of BMI on fasting insulin (change in natural log transformed fasting insulin: $0.17,95 \% \mathrm{Cl}: 0.15$ to $0.19, P=1.51 \times 10^{-}$ ${ }^{74}$ ), SHBG (change in INT SHBG: $-0.17,95 \% \mathrm{Cl}:-0.19$ to $-0.16, P=4.86 \times 10^{-125}$ ), bioavailable testosterone (change in INT bioavailable testosterone: $0.26,95 \% \mathrm{Cl}: 0.23$ to $0.29, P=9.97 \times 10^{-68}$ ), total testosterone (change in INT total testosterone: $0.08,95 \% \mathrm{Cl}: 0.05$ to $0.11, P=9.04 \times 10^{-10}$ ), and CRP (change in Intransformed CRP: $0.35,95 \% \mathrm{Cl}: 0.32$ to $0.38, P=2.67 \times 10^{-127}$ ) (Fig 6; Table 4). The direction of effect in MR analyses examining the effect of BMI on total testosterone was inconsistent when employing a weighted mode model, suggesting the potential presence of horizontal pleiotropy. Although there was 
medRxiv preprint doi: https://doi.org/10.1101/2021.12.10.21267599; this version posted December 13, 2021. The copyright holder for this preprint (which was not certified by peer review) is the author/funder, who has granted medRxiv a license to display the preprint in perpetuity.

It is made available under a CC-BY-NC-ND 4.0 International license .

little evidence for a causal effect of BMI on total serum cholesterol in the IVW model, there was some evidence for an effect across all three MR sensitivity analysis models, suggesting that horizontal pleiotropy may be biasing the IVW estimate towards the null. All other findings were consistent across the various sensitivity analyses (S23-S27 Figure, S8 Table, S17-S18 Table).

\section{Mendelian randomization mediation analysis}

In mediation analyses evaluating the potential mediating role of molecular traits previously shown to be on the causal pathway between $\mathrm{BMI}$ and endometrial cancer, there was evidence for a mediating role of bioavailable testosterone ( $15 \%$ mediated, $95 \% \mathrm{Cl}: 10$ to $20 \%, P=1.43 \times 10^{-8}$ ), fasting insulin (11\% of total effect mediated, $95 \% \mathrm{Cl}$ : 1 to $\left.21 \%, P=2.89 \times 10^{-2}\right)$, and SHBG (7\% mediated, $95 \% \mathrm{Cl}$ : 1 to $12 \%, P=1.81 \times 10^{-2}$ ) in the relationship between BMI and overall endometrial cancer risk (Table 5). There was also evidence for a mediating role of bioavailable testosterone (15\% mediated, $95 \% \mathrm{Cl}: 9$ to $\left.22 \%, P=2.15 \times 10^{-6}\right)$ and fasting insulin (16\% mediated, $95 \% \mathrm{Cl}: 1$ to $\left.21 \%, P=2.89 \times 10^{-2}\right)$ in the relationship between $\mathrm{BMI}$ and endometrioid endometrial cancer risk (Table 5). Although there was little evidence for a mediating role of SHBG in the relationship between sex-combined BMI and endometrioid endometrial cancer ( $2 \%$ mediated, $95 \% \mathrm{Cl}:-9$ to $14 \%, P=6.87 \times 10^{-1}$ ), in the female-specific BMI sensitivity analysis there was strong evidence for a mediating role of female-specific SHBG in the relationship between $\mathrm{BMI}$ and endometrioid endometrial cancer ( $8 \%$ mediated, $95 \% \mathrm{Cl}: 3$ to $13 \%, P=$ $\left.3.38 \times 10^{-3}\right)$. Other than this, findings were consistent across sex-specific BMI, fasting insulin and CRP sensitivity analyses (S28-S29 Table).

The conditional F-statistic for both fasting insulin (F=2) and $B M I(F=6)$ in the multivariable MR performed to evaluate the "proportion mediated" by fasting insulin was $<10$, indicating that there may 
medRxiv preprint doi: https://doi.org/10.1101/2021.12.10.21267599; this version posted December 13, 2021. The copyright holder for this preprint (which was not certified by peer review) is the author/funder, who has granted medRxiv a license to display the preprint in perpetuity.

It is made available under a CC-BY-NC-ND 4.0 International license .

317

318

319

320

321

322

323

324

be weak instrument bias in these analyses (i.e. over- or underestimation of the "proportion mediated" by fasting insulin) [56]. When re-performing the "proportion mediated" analysis for fasting insulin using an alternative approach (i.e. using an alternative fasting insulin instrument with a larger sample size and limiting the number of SNPs included in the BMI instrument to the 100 with the strongest evidence of association using an LD threshold $\left.r^{2}<0.001\right)$, we found that fasting insulin mediated $19 \%$ (95\% Cl: 5 to $\left.34 \%, P=9.17 \times 10^{-3}\right)$ of the relationship between $\mathrm{BMI}$ and overall endometrial cancer risk and $21 \%(95 \%$ $\mathrm{Cl}: 5$ to $38 \%, P=1.17 \times 10^{-2}$ ) of the relationship between $\mathrm{BMI}$ and endometrioid endometrial cancer risk (S30 Table).

In mediation analyses combining pairs of mediators into a single model, the effect of fasting insulin on overall endometrial cancer risk attenuated ( $\sim 40 \% \log$ OR reduction) when SHBG (a presumed downstream mediator of fasting insulin) was included in the model (OR per increase in natural log transformed $\mathrm{pmol} / \mathrm{L}$ fasting insulin: $2.28,95 \% \mathrm{Cl}: 1.34$ to $3.86, P=2.85 \times 10^{-3}$ ). The effect of SHBG on overall endometrial cancer attenuated fully when bioavailable testosterone (a presumed downstream mediator of SHBG) was included in the model (OR per increase in INT nmol/L SHBG: $1.08,95 \% \mathrm{Cl}: 0.86$ to 1.36, $\left.P=5.00 \times 10^{-1}\right)($ S34 Table). The effect of fasting insulin on overall endometrial cancer was strongly attenuated when bioavailable testosterone was included in the model (OR per increase in natural log transformed $\mathrm{pmol} / \mathrm{L}$ fasting insulin: $1.22,95 \% \mathrm{Cl}: 0.48$ to $3.11, \mathrm{P}=6.78 \times 10^{-1}$ ), which could reflect mediation of the effect of fasting insulin on endometrial cancer via bioavailable testosterone or the presence of conditionally weak instruments in this model. This could result in over- or underestimation of the proportion of the effect of fasting insulin mediated by bioavailable testosterone.

For the endometrioid histological subtype, using the same approach, the effect of fasting insulin on endometrioid endometrial cancer did not markedly change ( $14 \%$ logOR reduction) when SHBG was included in the model (OR per increase in natural log transformed pmol/L fasting insulin: $3.74,95 \% \mathrm{Cl}$ : 
medRxiv preprint doi: https://doi.org/10.1101/2021.12.10.21267599; this version posted December 13, 2021. The copyright holder for this preprint (which was not certified by peer review) is the author/funder, who has granted medRxiv a license to display the preprint in perpetuity. It is made available under a CC-BY-NC-ND 4.0 International license .

$340 \quad 0.74$ to $\left.19.01, P=1.56 \times 10^{-1}\right)$. However, the effect of SHBG on endometrioid endometrial cancer

341 attenuated fully when bioavailable testosterone was included in the model (OR per increase in INT

$342 \mathrm{nmol} / \mathrm{L} \mathrm{SHBG}: 1.16,95 \% \mathrm{Cl}: 0.81$ to $\left.1.65, \mathrm{P}=4.12 \times 10^{-1}\right)$. As with analyses of overall endometrial cancer,

343 when fasting insulin and bioavailable testosterone were combined into a single model, the effect of

344 fasting insulin on endometrioid endometrial cancer attenuated toward the null (OR per increase in

345 natural log transformed pmol/L fasting insulin: $1.05,95 \% \mathrm{Cl}: 0.36$ to $3.03, \mathrm{P}=9.33 \times 10^{-1}$ ), potentially

346 reflecting mediation via bioavailable testosterone or persistent weak instrument bias in this model. 
medRxiv preprint doi: https://doi.org/10.1101/2021.12.10.21267599; this version posted December 13, 2021. The copyright holder for this preprint (which was not certified by peer review) is the author/funder, who has granted medRxiv a license to display the preprint in perpetuity.

It is made available under a CC-BY-NC-ND 4.0 International license .

347

\section{Discussion}

Our systematic Mendelian randomization (MR) analysis of 14 previously reported molecular risk factors and body mass index (BMI) in 12,906 endometrial cancer cases and 108,979 controls provided evidence for roles of elevated BMI, fasting insulin, total and bioavailable testosterone, and sex hormone-binding globulin (SHBG) in risk of overall and endometrioid endometrial cancer. In mediation analyses, we found evidence that fasting insulin, bioavailable testosterone concentrations, and SHBG partially mediated the effect of BMI on overall endometrial cancer risk. When combining pairs of mediators together into a single model, we found evidence that an effect of fasting insulin on endometrial cancer was partially mediated by SHBG levels and that an effect of SHBG on endometrial cancer was largely mediated by bioavailable testosterone levels. An effect of fasting insulin on endometrial cancer risk was also strongly attenuated upon adjustment for bioavailable testosterone levels which could reflect mediation of this effect by bioavailable testosterone or conditionally weak instrument bias for fasting insulin concentrations in this analysis. Our analyses found little evidence that several previously reported molecular risk factors, including several metabolic factors (e.g. LDL-C, HDL-C, IGF-1, adiponectin, leptin) and inflammatory markers (CRP, IL-6), were causally implicated in overall or endometrioid endometrial cancer risk.

Several of the findings in this analysis are consistent with evidence from prior conventional observational and MR analyses. For example, the effect of BMI on endometrial cancer risk and the stronger evidence of an effect on endometrioid, as compared to non-endometrioid, endometrial cancer is well-established in the literature and has been shown previously in an MR analysis that used an alternative strategy for instrument construction. Our findings supporting a causal effect of BMI on endometrial cancer risk (OR $1.88,95 \% \mathrm{Cl}: 1.69$ to 2.09 per SD $\left(4.7 \mathrm{~kg} / \mathrm{m}^{2}\right)$ increase) are larger in magnitude than those from pooled analyses of conventional observational analyses (e.g. the World 
medRxiv preprint doi: https://doi.org/10.1101/2021.12.10.21267599; this version posted December 13, 2021. The copyright holder for this preprint (which was not certified by peer review) is the author/funder, who has granted medRxiv a license to display the preprint in perpetuity.

It is made available under a CC-BY-NC-ND 4.0 International license .

Cancer Research Fund (WCRF) pooled analysis of 26 prospective studies: RR 1.50, 95\% Cl 1.42 to 1.59

per $5.0 \mathrm{~kg} / \mathrm{m}^{2}$ increase), consistent with previous comparisons of observational and MR estimates across other cancer sites $[57,58]$. Smaller magnitudes of effect in observational analyses may reflect regression dilution bias from single time-point measurements of BMI and/or reverse causation from cancerinduced weight loss, whereas MR estimates reflect accumulated exposure across the life-course and are unlikely to be influenced by reverse causation [59].

In agreement with previous MR analyses, our results suggest a causal role of fasting insulin, total and bioavailable testosterone, and SHBG in endometrial cancer risk, although these previous reports either employed smaller sample sizes than this analysis (e.g. fasting insulin analyses were performed in 1,287 endometrial cancer cases vs 12,906 cases in our analysis) or used somewhat differing methods to examine instrumental variable assumptions [28-30]. The restriction of an effect of BMI to bioavailable (and not total) testosterone is in agreement with previous observational studies which have suggested that BMI influences testosterone levels through decreased production of SHBG rather than a direct effect on testosterone production [60-64]. Additionally, important mediating roles of fasting insulin, bioavailable testosterone, and SHBG in the relationship between BMI and endometrial cancer are consistent with studies of bariatric surgery which have suggested protective effects of this procedure against endometrial cancer risk, along with reductions in insulin and bioavailable testosterone levels, and increases in SHBG levels [65-73]. Our findings supporting a role of BMI on these traits are also consistent with the important endocrine function of adipose tissue, which is involved in sex steroid metabolism [62, 74-79].

Potential aetiological roles of the molecular mediators identified in this analysis are consistent with the "unopposed oestrogen" hypothesis which postulates that endometrial carcinogenesis is driven by excess endogenous or exogenous oestrogen levels that are unopposed by progesterone [80-82]. We 
medRxiv preprint doi: https://doi.org/10.1101/2021.12.10.21267599; this version posted December 13, 2021. The copyright holder for this preprint (which was not certified by peer review) is the author/funder, who has granted medRxiv a license to display the preprint in perpetuity.

It is made available under a CC-BY-NC-ND 4.0 International license .

were unable to incorporate oestrogen into this analysis as we were unable to identify reliable genetic instruments for this trait. All three of the molecular mediators highlighted in this analysis, however, are known to influence oestrogen: bioavailable testosterone is aromatized to oestradiol; SHBG binds with high-affinity to both oestradiol and bioavailable testosterone [82-87]; and insulin increases androgen and decreases SHBG production [88-91]. We found that an inverse effect of SHBG on endometrial cancer risk was largely attenuated upon adjustment for bioavailable testosterone, suggesting a protective effect of SHBG may be driven via binding of biologically active fractions of circulating testosterone. The attenuation of an effect of fasting insulin on endometrial cancer upon adjustment for bioavailable testosterone could reflect mediation of this effect or the presence of conditionally weak instrument bias in this model. In support of the latter explanation, there is biological evidence that hyperinsulinemia and insulin resistance influence endometrial cancer via oestrogen-independent pathways. For example, insulin has been shown to bind directly to endometrial cells and promote proliferation, and can activate two pathways known to have an important role in carcinogenesis - the phosphatidylinositol-3-kinaseprotein kinase B/Akt (PI3K-PKB/Akt) and Ras/Raf/mitogen-activated protein kinase (Ras/Raf/MAPK) pathways [91-96].

Some findings from this MR analysis are not in agreement with evidence from previous conventional observational studies. For example, our analyses found little evidence to support causal roles of several metabolic traits (e.g. circulating HDL-cholesterol, triglycerides, adiponectin, leptin) and inflammatory markers (CRP, IL-6) in endometrial cancer risk, despite these traits being linked to endometrial cancer risk in conventional observational analyses [18-22]. Several of these traits (e.g. HDLcholesterol, LDL-cholesterol, triglycerides) represent highly correlated metabolic perturbations associated with the obese phenotype which may be too clustered to disentangle using conventional multivariable regression methods [97]. Consequently, some of the divergence in findings across previous conventional observational studies and this MR analysis could reflect residual confounding in the 
medRxiv preprint doi: https://doi.org/10.1101/2021.12.10.21267599; this version posted December 13, 2021. The copyright holder for this preprint (which was not certified by peer review) is the author/funder, who has granted medRxiv a license to display the preprint in perpetuity.

It is made available under a CC-BY-NC-ND 4.0 International license .

417 former. Another potential explanation for divergence in findings is the susceptibility of conventional

418

419

420

421 observational studies to reverse causation (i.e., latent, undiagnosed endometrial cancer influencing levels of a presumed exposure). For example, a previously reported association of circulating IL-6 concentrations with endometrial cancer risk could reflect IL- 6 secretion by endometrial cancerassociated fibroblasts rather than a role of IL-6 in endometrial cancer development [98, 99].

We were unable to replicate a previously reported MR-based inverse association of LDL cholesterol levels and endometrial cancer risk in the Endometrial Cancer Association Consortium (IVW OR per SD increase in LDL cholesterol: $0.90,95 \% \mathrm{Cl}: 0.85$ to $\left.0.95, P=8.39 \times 10^{-5}\right)$. In the previous analysis, SNPs were permitted to be in weak linkage disequilibrium (LD) (pairwise correlation $r^{2}<0.05$ vs $r^{2}<0.001$ in our analysis) and a Heterogeneity in Dependent Instruments (HEIDI) test was performed to identify potentially pleiotropic SNPs, resulting in the removal of 6 such SNPs from the 146 SNPs initially used as an instrument. We attempted to replicate these previously reported findings using a more stringent $r^{2}$ threshold (i.e. $r^{2}<0.001$ ) followed by use of the HEIDI test (resulting in the removal of 2 potentially pleiotropic SNPs) which resulted in a causal estimate that was closer in magnitude to that previously reported (IVW OR 0.93, 95\% Cl: 0.86 to $1.00, P=4.10 \times 10^{-2}$ ) (S45 Table). However, there was greater imprecision in our estimate compared to this previous analysis which could reflect the more liberal LD threshold employed in this earlier analysis.

Our MR analysis provides key insights into potential molecular pathways linking excess adiposity to endometrial cancer risk. This analysis has several strengths including the use of a systematic approach to collate previously reported molecular risk factors for endometrial cancer; the appraisal of their causal relevance in overall and endometrioid endometrial cancer aetiology using an MR framework which should be less prone to conventional issues of confounding and cannot be influenced by reverse causation; the employment of several complementary sensitivity analyses to rigorously assess for 
medRxiv preprint doi: https://doi.org/10.1101/2021.12.10.21267599; this version posted December 13, 2021. The copyright holder for this preprint (which was not certified by peer review) is the author/funder, who has granted medRxiv a license to display the preprint in perpetuity.

It is made available under a CC-BY-NC-ND 4.0 International license .

440

441

442

violations of MR assumptions; and the use of a summary data-based MR approach which permitted us to leverage large-scale GWAS data from several studies, enhancing statistical power and precision of causal estimates.

There are several limitations to our analysis. First, we were unable to evaluate the role of six previously reported molecular risk factors for endometrial cancer due to the absence of reliable genetic instruments for these traits. These six risk factors included oestradiol which is believed to be an important molecular mediator of the effect of BMI on endometrial cancer risk[9]. Second, some of the effect estimates for SNPs included in genetic instruments were obtained from discovery GWAS and have not been replicated in an independent sample which can result in "Winner's curse" bias. There was sample overlap in this analysis across certain traits; however, the use of conventionally strong $(P<5.0 \mathrm{x}$ $\left.10^{-8}\right)$ instruments for these traits and the consistency of most findings in sensitivity analyses examining their robustness to potential Winner's curse bias suggests that this phenomenon was unlikely to markedly influence the results presented in this analysis. Third, although sex-specific sensitivity analyses were performed where data were available, some prior GWAS used in this analysis did not examine for heterogeneity of SNP effects by sex which prevented evaluation of the effect of certain traits on endometrial cancer risk using sex-specific instruments. Fourth, univariable and multivariable MR analyses presented here assume that relationships between exposures and outcomes are linear, although it has been previously suggested that the relationship between $\mathrm{BMI}$ and endometrial cancer may best be explained by a non-linear model $[12,100]$. Fifth, our analysis was almost exclusively restricted to individuals of European ancestry to minimise bias from population stratification, which may limit the generalisability of our findings to non-European populations. Finally, while various sensitivity analyses were performed to examine violations of exchangeability and exclusion restriction criteria, these assumptions are unverifiable. 
medRxiv preprint doi: https://doi.org/10.1101/2021.12.10.21267599; this version posted December 13, 2021. The copyright holder for this preprint (which was not certified by peer review) is the author/funder, who has granted medRxiv a license to display the preprint in perpetuity.

It is made available under a CC-BY-NC-ND 4.0 International license .

With the global incidence of overweight and obesity projected to increase and challenges in implementing successful weight loss strategies, pharmacological approaches targeting molecular mediators of the effect of obesity on endometrial cancer development may offer a viable approach for cancer prevention in high-risk groups [101-105]. Metformin, a safe and inexpensive first-line treatment for type 2 diabetes, could serve as a promising chemoprevention agent for endometrial cancer as it increases insulin sensitivity, thus reversing insulin resistance and lowering fasting insulin levels, alongside inhibiting endometrial proliferation $[9,106]$. In addition, unlike some other oral hypoglycaemic medications, metformin users show a tendency toward sustained weight loss [107] . Bioavailable testosterone and SHBG also present potential pharmacological targets, though the multifaceted function of these hormones means that targeting these traits may result in adverse effects [108-113]. Phase II clinical trials examining the efficacy of a combination of contraceptive intrauterine devices, metformin, and weight loss interventions as a non-invasive treatment option for individuals with obesity with early-stage endometrial cancer have had encouraging results, and weight loss has been shown to improve oncological outcomes in women with endometrial cancer undergoing progestin treatment $[114,115]$.

Our systematic evaluation of 14 previously reported candidate mediators of the effect of BMI on endometrial cancer risk identifies fasting insulin, bioavailable testosterone, and SHBG as plausible mediators of this relationship. While we were unable to entirely disentangle the independent effects of these three traits, identification of a potential mediating role of these traits (and, in particular, fasting insulin) in endometrial carcinogenesis is nonetheless informative for the development of pharmacological interventions targeting these traits for cancer prevention. In this respect, future assessment of the effect of drugs which target molecular mediators identified in this analysis using a "drug-target Mendelian randomization" approach could inform on the potential efficacy of the repurposing of medications for endometrial cancer prevention. 
medRxiv preprint doi: https://doi.org/10.1101/2021.12.10.21267599; this version posted December 13, 2021. The copyright holder for this preprint (which was not certified by peer review) is the author/funder, who has granted medRxiv a license to display the preprint in perpetuity. It is made available under a CC-BY-NC-ND 4.0 International license .

\section{Conclusion}

488 Our comprehensive Mendelian randomization analysis provides insight into potential causal

489 mechanisms linking excess adiposity to endometrial cancer risk. We show that lifelong cumulative 490 elevated BMI causes a larger increased risk than that reported in previous conventional observational 491 studies. We found strong evidence for a mediating role of fasting insulin, bioavailable testosterone and 492 SHBG in the effect of BMI on endometrial cancer risk. These results suggest pharmacological targeting of 493 insulin-related and hormonal traits as a potential strategy for the prevention of endometrial cancer. 
medRxiv preprint doi: https://doi.org/10.1101/2021.12.10.21267599; this version posted December 13, 2021. The copyright holder for this preprint (which was not certified by peer review) is the author/funder, who has granted medRxiv a license to display the preprint in perpetuity.

It is made available under a CC-BY-NC-ND 4.0 International license .

494

495

496

497

498

499

500

501

502

503

504

505

506

507

508

509

510

511

512

513

514

515

516

517

\section{Funding}

EH is supported by a Cancer Research UK Population Research Committee Studentship

(C18281/A30905). EH, VT, GDS, RMM, KR and JY are supported by Cancer Research UK (C18281/A29019)

programme grant (the Integrative Cancer Epidemiology Programme). EH, ES, VT, GDS, RMM, and JY are part of the Medical Research Council Integrative Epidemiology Unit at the University of Bristol which is supported by the Medical Research Council (MC_UU_00011/1, MC_UU_00011/3, MC_UU_00011/6, and MC_UU_00011/4) and the University of Bristol. JY is supported by a Cancer Research UK Population Research Postdoctoral Fellowship (C68933/A28534). RMM is also supported by the NIHR Bristol Biomedical Research Centre which is funded by the NIHR and is a partnership between University Hospitals Bristol and Weston NHS Foundation Trust and the University of Bristol. TMF is funded by the MRC (MR/T002239/1). TAO'M is funded by a National Health and Medical Research Council Investigator Fellowship (APP1173170).

Disclaimers: The views expressed are those of the author(s) and not necessarily those of the NHS, the NIHR or the Department of Health and Social Care; where authors are identified as personnel of the International Agency for Research on Cancer/World Health Organization, the authors alone are responsible for the views expressed in this article and they do not necessarily represent the decisions, policy, or views of the International Agency for Research on Cancer/World Health Organization.

\section{Acknowledgements}

The endometrial cancer genome-wide association analyses were supported by the National Health and Medical Research Council of Australia (APP552402, APP1031333, APP1109286, APP1111246 and APP1061779), the U.S. National Institutes of Health (R01-CA134958), European Research Council (EU FP7 Grant), Wellcome Trust Centre for Human Genetics (090532/Z/09Z) and Cancer Research UK. 
medRxiv preprint doi: https://doi.org/10.1101/2021.12.10.21267599; this version posted December 13 , 2021. The copyright holder for this preprint (which was not certified by peer review) is the author/funder, who has granted medRxiv a license to display the preprint in perpetuity.

It is made available under a CC-BY-NC-ND 4.0 International license .

518

519

520

521

522

523

524

Association Consortium (OCAC), which was funded through grants from the U.S. National Institutes of Health (CA1X01HG007491-01 (C.I. Amos), U19-CA148112 (T.A. Sellers), R01-CA149429 (C.M. Phelan) and R01-CA058598 (M.T. Goodman); Canadian Institutes of Health Research (MOP-86727 (L.E. Kelemen)) and the Ovarian Cancer Research Fund (A. Berchuck). We particularly thank the efforts of Cathy Phelan. OncoArray genotyping of the BCAC controls was funded by Genome Canada Grant GPH-129344, NIH Grant U19 CA148065, and Cancer UK Grant C1287/A16563. All studies and funders are listed in O'Mara et al (2018). The authors would like to thank the participants of the 1958 British birth cohort (BS58), Academic Medical Centre Amsterdam Premature Arosclerosis Study (AMC-PAS), Age, Gene/Environment Susceptibility (AGES) study, Anglo-Scandinavian Cardiac Outcome Trial (ASCOT), Aro-Express Biobank Study (AE), Arosclerosis Risk in Communities (ARIC) study, Arosclerotic Disease, Vascular Function, and Genetic Epidemiology (ADVANCE) study, Asian Indian Diabetic Heart Study (AIDHS) /Sikh Diabetes Study (SDS), Avon Longitudinal Study of Parents and Children (ALSPAC), Baltimore Longitudinal Study of Aging (BLSA), British Genetics of Hypertension (BRIGHT) Study, Busselton Health Study (BSN), C Reactive Protein Coronary Heart Disease Genetics Collaboration (CCGC), Cancer Prostate in Sweden 1 (CAPS1) study, Cancer Prostate in Sweden 2 (CAPS2) study, CardioGenics study, Cardiovascular Health Study (CHS), Cardiovascular Health Study (CHS), Cardiovascular Risk in Young Finns Study (YFS), Carotid Intima Media Thickness (IMT) and IMT-Progression as Predictors of Vascular Events in a High Risk European Population (IMPROVE) study, Cebu Longitudinal Health and Nutrition Survey (CLHNS), Charles Bronfman Institute for Personalized Medicine (IPM) BioMe Biobank Program, Cohorte Lausannoise (CoLaus) study, Cohorts for Heart and Aging Research in Genomic Epidemiology (CHARGE) Inflammation Working Group (CIWG), CROATIA-Vis study, Croatian Study (CROAS), Danish National Birth Cohort (DNBC), Data from an Epidemiological Study on Insulin Resistance syndrome (DESIR), Diabetes Epidemiology: Collaborative analysis of Diagnostic criteria in Europe (DECODE) study, Diabetes Genetics Initiative (DGI), DiaGen consortium, Dose-Responses to Exercise Training (DR's EXTRA) study, Dundee study, Dutch and Belgian 
medRxiv preprint doi: https://doi.org/10.1101/2021.12.10.21267599; this version posted December 13, 2021. The copyright holder for this preprint (which was not certified by peer review) is the author/funder, who has granted medRxiv a license to display the preprint in perpetuity.

It is made available under a CC-BY-NC-ND 4.0 International license .

542

543

544

545

546

547

548

549

550

551

552

553

554

555

556

557

558

559

560

561

562

563

564

565

Lung Cancer Screening Trial (NELSON), Echinococcus Multilocularis and Internal Diseases in Leutkirch (EMIL) study, Edinburgh Artery Study (EAS), Efficiency and safety of varying frequency of whole blood donation (INTERVAL) study, Ely Study, Endometrial Cancer Association Consortium (ECAC), Epidemiology of Endometrial Cancer Consortium (E2C2), EpiHealth cohort, Erasmus Rucphen Family (ERF) study, Estonian Biobank, Estonian Genome Center of University of Tartu (EGCUT) study, European Prospective Investigation into Cancer and Nutrition (EPIC) study, Family Blood Pressure Program (FBPP), Family Blood Pressure Program (FBPP), Family Heart Study (FamHS), Fast Revascularisation during Instability in Coronary artery disease (FRISCII) study, Fendland study, Finland-United States Investigation of NIDDM Genetics (FUSION) study, FinMetSeq, Finnish Cardiovascular Study (FINCAVAS), Finnish Diabetes Prevention Study (DPS), Finnish Genetic Study of Arrhythmic Events (FinGesture), Finnish National Diabetes Prevention Program (FIN-D2D), Finnish Twin Cohort (FTC), Finrisk study, Framingham Heart Study (FRAM), Genetic Investigation of ANthropometric Traits (GIANT), Gene-Lifestyle interactions And Complex traits Involved in Elevated disease Risk Study (GLACIER), Genetic determinants of Obesity and Metabolic syndrome (DILGOM) study, Genetic Epidemiology Network of Arteriopathy (GENOA) study, Genetic Predisposition of Coronary Heart Disease in Patients Verified with Coronary Angiogram (COROGENE), Genetics of Diabetes Audit and Research Study (GoDartS), GenomEUtwin, German Myocard Infarct Family Study I (GerMiFSI), German Myocard Infarct Family Study II (GerMiFSII), Global Lipids Consortium (GLGC), Gonburg Osteoporosis and Obesity Determinants Study (GOOD), Health 2000 study, Health and Retirement Study (HRS), Health, Aging, and Body Composition Study (Health ABC), Health, Risk Factors, Training and Genetics (HERITAGE) Family Study, Heinz Nixdorf Recall (HNR), Hellenic study of Interactions between Single nucleotide polymorphisms and Eating in Arosclerosis Susceptibility (THISEAS), Helsinki Birth Cohort Study (HBCS), Heredity and Phenotype Intervention (HAPI) Heart Study, Invecchiare in Chianti (InCHIANTI) study, Kingston Gene-by-environment; subset of International Collaborative Study of Hypertension in Blacks (GXE), Kooperative Gesundheitsforschung in 
medRxiv preprint doi: https://doi.org/10.1101/2021.12.10.21267599; this version posted December 13, 2021. The copyright holder for this preprint (which was not certified by peer review) is the author/funder, who has granted medRxiv a license to display the preprint in perpetuity.

It is made available under a CC-BY-NC-ND 4.0 International license .

566

567

568

569

570

571

572

der Region Augsburg (KORA) study, Korcula study, Leiden Longevity Study (LLS), Leipzig adults study, Leipzig kids study, Lifelines cohort, London Life Sciences Prospective Population Study (LOLIPOP), LUdwigshafen RIsk and Cardiovascular Health (LURIC) study, MAGIC (the Meta-Analyses of Glucose and Insulin-related traits Consortium), Malmo Preventive Project-Re-examination (MPP-RES) study, Malmo Diet and Cancer Study (MDC), Medical research Council (MRC) National Survey of Health \& Development (MRC NSHD), Medical Research Council (MRC) National Survey of Health and Development (NSHD), Medical Research Council/Uganda Virus Research Institute General Population Cohort (MRC/UVRIGPC), Metabolic Syndrome in Men (METSIM) study, Microisolates in South Tyrol Study (MICROS), Molecular Genetics of Schizophrenia (MGS), MOnica Risk, Genetics, Archiving and Monograph (MORGAM), Multiethnic Cohort Study (MEC), Myocardial Infarction Genetics Consortium (Migen), Nerlands Study of Depression and Anxiety (NESDA), Nerlands Twin Register (NTR), Nijmegen Bladder Cancer Study and Nijmegen Biomedical Study (RUNMC), Nord- Trøndelag Health Study (HUNT), Northern Finland Birth Cohort 1966 (NFBC66), Northern Finland Birth Cohort 1986 (NFBC86), Northern Sweden Population Health Study (NSPHS), Nurse's Health Study (NHS), Orkney Complex Disease Study (ORCADES), Pakistan Risk of Myocardial Infarction Study (PROMIS), Precocious Coronary Artery Disease (PROCARDIS) study, Prevention of REnal and Vascular ENd-stage Disease (PREVEND) study, Prospective Investigation of Vasculature in Uppsala Seniors (PIVUS) study, PROspective study of Pravastatin in Elderly at Risk for vascular disease (PROSPER/PHASE), Prostate, Lung, Colorectal and Ovarian Cancer Screening Trial (PLCO), Quebec Family Study (QFS), Relationship between Insulin Sensitivity and Cardiovascular disease Study (RISC), Rotterdam study, SardiNIA Project, Seychelles Family Study (TANDEM), Sorbs study, Spanish Town study (SPT), STabilization of Arosclerotic plaque By Initiation of darapLadlb rapY (STABILITY), Stanley cohort, Stockholm Coronary Arosclerosis Risk Factor (SCARF) study, Stockholm Heart Epidemiology Program (SHEEP), Studies of Epidemiology and Risk factors in Cancer Heredity / UK Ovarian Cancer Population Study (SEARCH/UKOPS), Study of Health in Pomerania (SHIP), Suivi 
medRxiv preprint doi: https://doi.org/10.1101/2021.12.10.21267599; this version posted December 13, 2021. The copyright holder for this preprint (which was not certified by peer review) is the author/funder, who has granted medRxiv a license to display the preprint in perpetuity. It is made available under a CC-BY-NC-ND 4.0 International license .

590 Temporaire Annuel Non Invasif de la Santé des Lorrains Assurés Sociaux (STANISLAS) cohort, Swedish

591 And Singapore Breast Association Consortium (SASBAC), Swedish Twin Registry (STR), Taichi Consortium,

592 Tracking Adolescents' Individual Lives Survey (TRAILS), Troms $\varnothing$ Study, Twin study at Queensland Institute

593 of Medical Research (QIMR), Twins UK, UK Biobank, Uppsala Longitudinal Study of Adult Men (ULSAM),

594 Vitamin D and Type 2 Diabetes (D2d) study, Wellcome Trust Case Control Consortium (WTCCC),

595 Whitehall study, Women's Genome Health Study (WGHS), and Women's Health Initiative (WHI) for their

596 participation in these studies along with the principal investigators for generating the data utilised for

597 this analysis and for making these data available in the public domain. Data on glycaemic traits have

598 been contributed by MAGIC investigators and have been downloaded from

599 www.magicinvestigators.org, and data on oestradiol and blood glucose have been contributed by the

600 Neale lab and have been downloaded from www.nealelab.is. 
medRxiv preprint doi: https://doi.org/10.1101/2021.12.10.21267599; this version posted December 13 , 2021. The copyright holder for this preprint (which was not certified by peer review) is the author/funder, who has granted medRxiv a license to display the preprint in perpetuity.

It is made available under a CC-BY-NC-ND 4.0 International license .

601

602

603

604

605

606

607

608

609

610

611

612

613

614

615

616

617

618

619

620

621

\section{References}

1. Bray F, Ferlay J, Soerjomataram I, Siegel RL, Torre LA, Jemal A. Global cancer statistics

2018: GLOBOCAN estimates of incidence and mortality worldwide for 36 cancers in 185

countries. CA: A Cancer Journal for Clinicians. 2018;68(6):394-424. doi:

\section{https://doi.org/10.3322/caac.21492.}

2. Howlader N NA, Krapcho M, Miller D, Bishop K, Kosary CL, Yu M, Ruhl J, Tatalovich Z, Mariotto A, Lewis DR, Chen HS, Feuer EJ, Cronin KA (eds). SEER Cancer Statistics Review, 19752014, National Cancer Institute. Bethesda, MD, https://seercancergov/csr/1975 2014/. Based on November 2016 SEER data submission, posted to the SEER web site, April 2017.

3. Sung H, Ferlay J, Siegel RL, Laversanne M, Soerjomataram I, Jemal A, et al. Global Cancer Statistics 2020: GLOBOCAN Estimates of Incidence and Mortality Worldwide for 36 Cancers in 185 Countries. CA Cancer J Clin. 2021;71(3):209-49. Epub 2021/02/05. doi: 10.3322/caac.21660. PubMed PMID: 33538338.

4. Sheikh MA, Althouse AD, Freese KE, Soisson S, Edwards RP, Welburn S, et al. USA Endometrial Cancer Projections to 2030: should we be concerned? Future Oncology. 2014;10(16):2561-8. doi: 10.2217/fon.14.192. PubMed PMID: 25531045.

5. Lortet-Tieulent J, Ferlay J, Bray F, Jemal A. International Patterns and Trends in Endometrial Cancer Incidence, 1978-2013. JNCI: Journal of the National Cancer Institute. 2017;110(4):354-61. doi: 10.1093/jnci/djx214.

6. Siegel RL, Miller KD, Jemal A. Cancer statistics, 2016. CA: A Cancer Journal for Clinicians. 2016;66(1):7-30. doi: https://doi.org/10.3322/caac.21332. 
medRxiv preprint doi: https://doi.org/10.1101/2021.12.10.21267599; this version posted December 13 , 2021. The copyright holder for this preprint (which was not certified by peer review) is the author/funder, who has granted medRxiv a license to display the preprint in perpetuity.

It is made available under a CC-BY-NC-ND 4.0 International license .

622 7. Zhang S, Gong T-T, Liu F-H, Jiang Y-T, Sun H, Ma X-X, et al. Global, Regional, and National

623

624

625

626

627

628

629

630

631

632

633

634

635

636

637

638

639

640

641

642

643

Burden of Endometrial Cancer, 1990-2017: Results From the Global Burden of Disease Study, 2017. Front Oncol. 2019;9:1440-. doi: 10.3389/fonc.2019.01440. PubMed PMID: 31921687.

8. Mullins MA, Cote ML. Beyond Obesity: The Rising Incidence and Mortality Rates of Uterine Corpus Cancer. J Clin Oncol. 2019;37(22):1851-3. Epub 2019/06/20. doi:

10.1200/JCO.19.01240. PubMed PMID: 31232669.

9. Onstad MA, Schmandt RE, Lu KH. Addressing the Role of Obesity in Endometrial Cancer Risk, Prevention, and Treatment. J Clin Oncol. 2016;34(35):4225-30. Epub 2016/11/07. doi: 10.1200/JCO.2016.69.4638. PubMed PMID: 27903150.

10. Lega IC, Lipscombe LL. Review: Diabetes, Obesity, and Cancer-Pathophysiology and Clinical Implications. Endocrine Reviews. 2019;41(1):33-52. doi: 10.1210/endrev/bnz014.

11. Reeves GK, Pirie K, Beral V, Green J, Spencer E, Bull D, et al. Cancer incidence and mortality in relation to body mass index in the Million Women Study: cohort study. BMJ. 2007;335(7630):1134-. Epub 2007/11/06. doi: 10.1136/bmj.39367.495995.AE. PubMed PMID: 17986716.

12. Aune D, Navarro Rosenblatt DA, Chan DS, Vingeliene S, Abar L, Vieira AR, et al. Anthropometric factors and endometrial cancer risk: a systematic review and dose-response meta-analysis of prospective studies. Ann Oncol. 2015;26(8):1635-48. Epub 2015/03/21. doi: 10.1093/annonc/mdv142. PubMed PMID: 25791635.

13. World Cancer Research Fund/American Institute for Cancer Research. Continuous Update Project Expert Report 2018. Diet, nutrition, physical activity and ovarian cancer. Available at dietandcancerreport.org. 
medRxiv preprint doi: https://doi.org/10.1101/2021.12.10.21267599; this version posted December 13 , 2021. The copyright holder for this preprint (which was not certified by peer review) is the author/funder, who has granted medRxiv a license to display the preprint in perpetuity.

It is made available under a CC-BY-NC-ND 4.0 International license .

644

645

646

647

648

649

650

651

652

653

654

655

656

657

658

659

660

661

662

663

664

14. World Cancer Research Fund/American Institute for Cancer Research. Continuous

Update Project Expert Report 2018. Diet, nutrition, physical activity and oesophageal cancer.

Available at dietandcancerreport.org.

15. Nevadunsky NS, Van Arsdale A, Strickler HD, Moadel A, Kaur G, Levitt J, et al. Obesity

and age at diagnosis of endometrial cancer. Obstet Gynecol. 2014;124(2 Pt 1):300-6. Epub

2014/07/09. doi: 10.1097/aog.0000000000000381. PubMed PMID: 25004350.

16. McCullough ML, Patel AV, Patel R, Rodriguez C, Feigelson HS, Bandera EV, et al. Body

mass and endometrial cancer risk by hormone replacement therapy and cancer subtype.

Cancer Epidemiol Biomarkers Prev. 2008;17(1):73-9. Epub 2008/01/12. doi: 10.1158/1055-

9965.Epi-07-2567. PubMed PMID: 18187388.

17. Painter JN, O'Mara TA, Marquart L, Webb PM, Attia J, Medland SE, et al. Genetic Risk

Score Mendelian Randomization Shows that Obesity Measured as Body Mass Index, but not

Waist:Hip Ratio, Is Causal for Endometrial Cancer. Cancer epidemiology, biomarkers \&

prevention : a publication of the American Association for Cancer Research, cosponsored by the

American Society of Preventive Oncology. 2016;25(11):1503-10. Epub 2016/08/22. doi:

10.1158/1055-9965.EPI-16-0147. PubMed PMID: 27550749.

18. Dossus L, Rinaldi S, Becker S, Lukanova A, Tjonneland A, Olsen A, et al. Obesity, inflammatory markers, and endometrial cancer risk: a prospective case-control study. Endocrine-Related Cancer. 2010;17(4):1007. doi: 10.1677/erc-10-0053.

19. Friedenreich CM, Langley AR, Speidel TP, Lau DCW, Courneya KS, Csizmadi I, et al. Casecontrol study of inflammatory markers and the risk of endometrial cancer. European Journal of 
medRxiv preprint doi: https://doi.org/10.1101/2021.12.10.21267599; this version posted December 13 , 2021. The copyright holder for this preprint (which was not certified by peer review) is the author/funder, who has granted medRxiv a license to display the preprint in perpetuity.

It is made available under a CC-BY-NC-ND 4.0 International license .

665

666

667

668

669

670

671

672

673

674

675

676

677

678

679

680

681

682

683

684

685

Cancer Prevention. 2013;22(4):374-9. doi: 10.1097/CEJ.0b013e32835b3813. PubMed PMID: 00008469-201307000-00013.

20. Wang T, Rohan TE, Gunter MJ, Xue X, Wactawski-Wende J, Rajpathak SN, et al. A

Prospective Study of Inflammation Markers and Endometrial Cancer Risk in Postmenopausal Hormone Nonusers. Cancer Epidemiology Biomarkers \&amp; Prevention. 2011;20(5):971-7. doi: 10.1158/1055-9965.Epi-10-1222.

21. Lindemann K, Vatten $L$, Ellstrøm-Engh M, Eskild A. Serum lipids and endometrial cancer risk: Results from the HUNT-II study. International Journal of Cancer. 2009;124(12):2938-41. doi: https://doi.org/10.1002/iic.24285.

22. Swanson CA, Potischman N, Barrett RJ, Berman ML, Mortel R, Twiggs LB, et al. Endometrial cancer risk in relation to serum lipids and lipoprotein levels. Cancer Epidemiol Biomarkers Prev. 1994;3(7):575-81. Epub 1994/10/01. PubMed PMID: 7827588.

23. Yarmolinsky J, Wade KH, Richmond RC, Langdon RJ, Bull CJ, Tilling KM, et al. Causal Inference in Cancer Epidemiology: What Is the Role of Mendelian Randomization? Cancer Epidemiology Biomarkers \&amp; Prevention. 2018;27(9):995-1010. doi: 10.1158/10559965.Epi-17-1177.

24. Davey Smith G, Ebrahim S. 'Mendelian randomization': can genetic epidemiology contribute to understanding environmental determinants of disease?*. International Journal of Epidemiology. 2003;32(1):1-22. doi: 10.1093/ije/dyg070.

25. Pierce BL, Burgess S. Efficient design for Mendelian randomization studies: subsample and 2-sample instrumental variable estimators. Am J Epidemiol. 2013;178(7):1177-84. Epub 
medRxiv preprint doi: https://doi.org/10.1101/2021.12.10.21267599; this version posted December 13 , 2021. The copyright holder for this preprint (which was not certified by peer review) is the author/funder, who has granted medRxiv a license to display the preprint in perpetuity.

It is made available under a CC-BY-NC-ND 4.0 International license.

686

687

688

689

690

691

692

693

694

695

696

697

698

699

700

701

702

703

704

705

706

707

2013/07/19. doi: 10.1093/aje/kwt084. PubMed PMID: 23863760; PubMed Central PMCID:

PMCPMC3783091.

26. Thompson DJ, O'Mara TA, Glubb DM, Painter JN, Cheng T, Folkerd E, et al. CYP19A1 finemapping and Mendelian randomization: estradiol is causal for endometrial cancer. Endocr Relat Cancer. 2016;23(2):77-91. Epub 2015/11/18. doi: 10.1530/erc-15-0386. PubMed PMID:

26574572; PubMed Central PMCID: PMCPMC4697192.

27. Kho P-F, Amant F, Annibali D, Ashton K, Attia J, Auer PL, et al. Mendelian randomization analyses suggest a role for cholesterol in the development of endometrial cancer. International Journal of Cancer. 2021;148(2):307-19. doi: https://doi.org/10.1002/iic.33206.

28. Nead KT, Sharp SJ, Thompson DJ, Painter JN, Savage DB, Semple RK, et al. Evidence of a Causal Association Between Insulinemia and Endometrial Cancer: A Mendelian Randomization Analysis. J Natl Cancer Inst. 2015;107(9). Epub 2015/07/03. doi: 10.1093/jnci/djv178. PubMed PMID: 26134033; PubMed Central PMCID: PMCPMC4572886.

29. Ruth KS, Day FR, Tyrrell J, Thompson DJ, Wood AR, Mahajan A, et al. Using human genetics to understand the disease impacts of testosterone in men and women. Nature Medicine. 2020;26(2):252-+. doi: 10.1038/s41591-020-0751-5. PubMed PMID: WOS:000512529400005.

30. Mullee A, Dimou N, Allen N, O'Mara T, Gunter MJ, Murphy N. Testosterone, sex hormone-binding globulin, insulin-like growth factor-1 and endometrial cancer risk: observational and Mendelian randomization analyses. Br J Cancer. 2021;125(9):1308-17. Epub 2021/08/08. doi: 10.1038/s41416-021-01518-3. PubMed PMID: 34363033; PubMed Central PMCID: PMCPMC8548546. 
medRxiv preprint doi: https://doi.org/10.1101/2021.12.10.21267599; this version posted December 13 , 2021. The copyright holder for this preprint (which was not certified by peer review) is the author/funder, who has granted medRxiv a license to display the preprint in perpetuity.

It is made available under a CC-BY-NC-ND 4.0 International license.

708

709

710

711

712

713

714

715

716

717

718

719

720

721

722

723

724

725

726

727

31. O'Mara TA, Glubb DM, Amant F, Annibali D, Ashton K, Attia J, et al. Identification of nine new susceptibility loci for endometrial cancer. Nat Commun. 2018;9(1):3166. Epub 2018/08/11. doi: 10.1038/s41467-018-05427-7. PubMed PMID: 30093612; PubMed Central PMCID:

PMCPMC6085317.

32. Dimou NL, Papadimitriou N, Mariosa D, Johansson M, Brennan P, Peters U, et al. Circulating adipokine concentrations and risk of five obesity-related cancers: A Mendelian randomization study. Int J Cancer. 2021;148(7):1625-36. Epub 2020/10/11. doi:

10.1002/ijc.33338. PubMed PMID: 33038280; PubMed Central PMCID: PMCPMC7894468.

33. Auton A, Abecasis GR, Altshuler DM, Durbin RM, Abecasis GR, Bentley DR, et al. A global reference for human genetic variation. Nature. 2015;526(7571):68-74. doi:

10.1038/nature15393.

34. Willer CJ, Schmidt EM, Sengupta S, Peloso GM, Gustafsson S, Kanoni S, et al. Discovery and refinement of loci associated with lipid levels. Nature Genetics. 2013;45(11):1274-+. doi: 10.1038/ng.2797. PubMed PMID: WOS:000326384100007.

35. Scott RA, Lagou V, Welch RP, Wheeler E, Montasser ME, Luan JA, et al. Large-scale association analyses identify new loci influencing glycemic traits and provide insight into the underlying biological pathways. Nature Genetics. 2012;44(9):991-+. doi: 10.1038/ng.2385.

PubMed PMID: WOS:000308491200010.

36. Neale B. GWAS results. UK Biobank website. [updated 1st August 2018; cited 2020 $9 / 12 / 20]$. 
medRxiv preprint doi: https://doi.org/10.1101/2021.12.10.21267599; this version posted December 13, 2021. The copyright holder for this preprint (which was not certified by peer review) is the author/funder, who has granted medRxiv a license to display the preprint in perpetuity.

It is made available under a CC-BY-NC-ND 4.0 International license .

37. Sinnott-Armstrong N, Tanigawa Y, Amar D, Mars NJ, Aguirre M, Venkataraman GR, et al.

Genetics of 38 blood and urine biomarkers in the UK Biobank. bioRxiv. 2019:660506. doi:

$10.1101 / 660506$.

38. Georgakis MK, Malik R, Gill D, Franceschini N, Sudlow CLM, Dichgans M. Interleukin-6 signaling effects on ischemic stroke and other cardiovascular outcomes: a Mendelian Randomization study. medRxiv. 2019:19007682. doi: 10.1101/19007682.

39. Dastani Z, Hivert M-F, Timpson N, Perry JRB, Yuan X, Scott RA, et al. Novel Loci for Adiponectin Levels and Their Influence on Type 2 Diabetes and Metabolic Traits: A Multi-Ethnic Meta-Analysis of 45,891 Individuals. PLOS Genetics. 2012;8(3):e1002607. doi:

10.1371/journal.pgen.1002607.

40. Sun BB, Maranville JC, Peters JE, Stacey D, Staley JR, Blackshaw J, et al. Genomic atlas of the human plasma proteome. Nature. 2018;558(7708):73-9. doi: 10.1038/s41586-018-0175-2.

41. Ligthart S, Vaez A, Võsa U, Stathopoulou MG, de Vries PS, Prins BP, et al. Genome Analyses of $>200,000$ Individuals Identify 58 Loci for Chronic Inflammation and Highlight Pathways that Link Inflammation and Complex Disorders. Am J Hum Genet. 2018;103(5):691706. Epub 2018/11/06. doi: 10.1016/j.ajhg.2018.09.009. PubMed PMID: 30388399; PubMed Central PMCID: PMC6218410.

42. Yengo L, Sidorenko J, Kemper KE, Zheng Z, Wood AR, Weedon MN, et al. Meta-analysis of genome-wide association studies for height and body mass index in $\sim 700000$ individuals of European ancestry. Hum Mol Genet. 2018;27(20):3641-9. Epub 2018/08/21. doi:

10.1093/hmg/ddy271. PubMed PMID: 30124842; PubMed Central PMCID: PMCPMC6488973. 
medRxiv preprint doi: https://doi.org/10.1101/2021.12.10.21267599; this version posted December 13 , 2021. The copyright holder for this preprint (which was not certified by peer review) is the author/funder, who has granted medRxiv a license to display the preprint in perpetuity.

It is made available under a CC-BY-NC-ND 4.0 International license .

749

750

751

752

753

754

755

756

757

758

759

760

761

762

43. Davies NM, Holmes MV, Davey Smith G. Reading Mendelian randomisation studies: a guide, glossary, and checklist for clinicians. BMJ. 2018;362:k601. Epub 2018/07/14. doi:

10.1136/bmj.k601. PubMed PMID: 30002074; PubMed Central PMCID: PMCPMC6041728 interests and declare that we have no competing interests.

44. Burgess S, Zuber V, Valdes-Marquez E, Sun BB, Hopewell JC. Mendelian randomization with fine-mapped genetic data: Choosing from large numbers of correlated instrumental variables. Genetic Epidemiology. 2017;41(8):714-25. doi: https://doi.org/10.1002/gepi.22077.

45. Hemani G, Bowden J, Davey Smith G. Evaluating the potential role of pleiotropy in Mendelian randomization studies. Hum Mol Genet. 2018;27(R2):R195-r208. Epub 2018/05/18. doi: 10.1093/hmg/ddy163. PubMed PMID: 29771313; PubMed Central PMCID:

PMCPMC6061876.

46. Bowden J, Davey Smith G, Haycock PC, Burgess S. Consistent Estimation in Mendelian Randomization with Some Invalid Instruments Using a Weighted Median Estimator. Genet Epidemiol. 2016;40(4):304-14. Epub 2016/04/12. doi: 10.1002/gepi.21965. PubMed PMID: 27061298; PubMed Central PMCID: PMCPMC4849733.

47. Hartwig FP, Davey Smith G, Bowden J. Robust inference in summary data Mendelian randomization via the zero modal pleiotropy assumption. International journal of epidemiology. 2017;46(6):1985-98. doi: 10.1093/ije/dyx102. PubMed PMID: 29040600.

48. Bowden J, Davey Smith G, Burgess S. Mendelian randomization with invalid instruments: effect estimation and bias detection through Egger regression. Int J Epidemiol. 2015;44(2):512-

25. Epub 2015/06/08. doi: 10.1093/ije/dyv080. PubMed PMID: 26050253; PubMed Central

PMCID: PMCPMC4469799. 
medRxiv preprint doi: https://doi.org/10.1101/2021.12.10.21267599; this version posted December 13 , 2021. The copyright holder for this preprint (which was not certified by peer review) is the author/funder, who has granted medRxiv a license to display the preprint in perpetuity.

It is made available under a CC-BY-NC-ND 4.0 International license .

771 49. Hemani G, Tilling K, Davey Smith G. Orienting the causal relationship between

772 imprecisely measured traits using GWAS summary data. PLoS Genet. 2017;13(11):e1007081.

773

774

775

776

777

778

779

780

781

782

783

784

785

786

787

788

789

790

791

792

Epub 2017/11/18. doi: 10.1371/journal.pgen.1007081. PubMed PMID: 29149188; PubMed

Central PMCID: PMCPMC5711033.

50. Burgess S, Thompson SG. Multivariable Mendelian Randomization: The Use of

Pleiotropic Genetic Variants to Estimate Causal Effects. American Journal of Epidemiology. 2015;181(4):251-60. doi: 10.1093/aje/kwu283.

51. Cheung MWL. Comparison of methods for constructing confidence intervals of standardized indirect effects. Behavior Research Methods. 2009;41(2):425-38. doi:

10.3758/BRM.41.2.425.

52. Haycock PC, Burgess S, Wade KH, Bowden J, Relton C, Davey Smith G. Best (but oftforgotten) practices: the design, analysis, and interpretation of Mendelian randomization studies. Am J Clin Nutr. 2016;103(4):965-78. doi: 10.3945/ajcn.115.118216. PubMed PMID: 26961927.

53. Kettunen J, Demirkan A, Würtz P, Draisma HH, Haller T, Rawal R, et al. Genome-wide study for circulating metabolites identifies 62 loci and reveals novel systemic effects of LPA. Nat Commun. 2016;7:11122. Epub 2016/03/24. doi: 10.1038/ncomms11122. PubMed PMID: 27005778.

54. Prins BP, Kuchenbaecker KB, Bao Y, Smart M, Zabaneh D, Fatemifar G, et al. Genomewide analysis of health-related biomarkers in the UK Household Longitudinal Study reveals novel associations. Sci Rep. 2017;7(1):11008. Epub 2017/09/10. doi: 10.1038/s41598-01710812-1. PubMed PMID: 28887542; PubMed Central PMCID: PMCPMC5591265. 
medRxiv preprint doi: https://doi.org/10.1101/2021.12.10.21267599; this version posted December 13 , 2021. The copyright holder for this preprint (which was not certified by peer review) is the author/funder, who has granted medRxiv a license to display the preprint in perpetuity.

It is made available under a CC-BY-NC-ND 4.0 International license.

793

794

795

796

797

798

799

800

801

802

803

804

805

806

807

808

809

810

811

812

813

55. Locke AE, Kahali B, Berndt SI, Justice AE, Pers TH, Felix R, et al. Genetic studies of body mass index yield new insights for obesity biology. Nature. 2015;518(7538):197-U401. doi: 10.1038/nature14177. PubMed PMID: WOS:000349190300031.

56. Sanderson E, Spiller W, Bowden J. Testing and Correcting for Weak and Pleiotropic Instruments in Two-Sample Multivariable Mendelian Randomisation. bioRxiv. 2020:2020.04.02.021980. doi: 10.1101/2020.04.02.021980.

57. World Cancer Research Fund/American Institute for Cancer Research. Continuous Update Project Expert Report 2018. Diet, nutrition, physical activity and endometrial cancer. Available at dietandcancerreport.org.

58. Mariosa D, Carreras-Torres R, Martin RM, Johansson M, Brennan P. Commentary: What can Mendelian randomization tell us about causes of cancer? International Journal of Epidemiology. 2019;48(3):816-21. doi: 10.1093/ije/dyz151.

59. Morris TT, Heron J, Sanderson E, Smith GD, Tilling K. Interpretation of mendelian randomization using one measure of an exposure that varies over time. medRxiv. 2021:2021.11.18.21266515. doi: 10.1101/2021.11.18.21266515.

60. Poddar M, Chetty Y, Chetty VT. How does obesity affect the endocrine system? A narrative review. Clinical Obesity. 2017;7(3):136-44. doi: https://doi.org/10.1111/cob.12184. 61. Danforth KN, Eliassen AH, Tworoger SS, Missmer SA, Barbieri RL, Rosner BA, et al. The association of plasma androgen levels with breast, ovarian and endometrial cancer risk factors among postmenopausal women. International journal of cancer. 2010;126(1):199-207. doi: 10.1002/ijc.24709. PubMed PMID: 19569181. 
medRxiv preprint doi: https://doi.org/10.1101/2021.12.10.21267599; this version posted December 13 , 2021. The copyright holder for this preprint (which was not certified by peer review) is the author/funder, who has granted medRxiv a license to display the preprint in perpetuity.

It is made available under a CC-BY-NC-ND 4.0 International license .

814

815

816

817

818

819

820

821

822

823

824

825

826

827

828

829

830

831

832

833

834

62. Penttilä T-L, Koskinen P, Penttilä T-A, Anttila L, Irjala K. Obesity regulates bioavailable testosterone levels in women with or without polycystic ovary syndrome. Fertility and Sterility. 1999;71(3):457-61. doi: https://doi.org/10.1016/S0015-0282(98)00473-7.

63. Lim SS, Norman RJ, Davies MJ, Moran L. The effect of obesity on polycystic ovary syndrome: a systematic review and meta-analysis. Obesity Reviews. 2013;14(2):95-109. doi: https://doi.org/10.1111/i.1467-789X.2012.01053.x.

64. Burger HG, Dudley EC, Cui J, Dennerstein L, Hopper JL. A prospective longitudinal study of serum testosterone, dehydroepiandrosterone sulfate, and sex hormone-binding globulin levels through the menopause transition. J Clin Endocrinol Metab. 2000;85(8):2832-8. Epub 2000/08/18. doi: 10.1210/jcem.85.8.6740. PubMed PMID: 10946891.

65. Upala S, Anawin S. Bariatric surgery and risk of postoperative endometrial cancer: a systematic review and meta-analysis. Surgery for Obesity and Related Diseases. 2015;11(4):949-

55. doi: https://doi.org/10.1016/i.soard.2014.09.024.

66. Sjöström L, Gummesson A, Sjöström CD, Narbro K, Peltonen M, Wedel H, et al. Effects of bariatric surgery on cancer incidence in obese patients in Sweden (Swedish Obese Subjects Study): a prospective, controlled intervention trial. Lancet Oncol. 2009;10(7):653-62. Epub 2009/06/27. doi: 10.1016/s1470-2045(09)70159-7. PubMed PMID: 19556163.

67. Anderwald CH, Tura A, Promintzer-Schifferl M, Prager G, Stadler M, Ludvik B, et al. Alterations in gastrointestinal, endocrine, and metabolic processes after bariatric Roux-en- $Y$ gastric bypass surgery. Diabetes Care. 2012;35(12):2580-7. Epub 2012/08/28. doi:

10.2337/dc12-0197. PubMed PMID: 22923664; PubMed Central PMCID: PMCPMC3507557. 
medRxiv preprint doi: https://doi.org/10.1101/2021.12.10.21267599; this version posted December 13 , 2021. The copyright holder for this preprint (which was not certified by peer review) is the author/funder, who has granted medRxiv a license to display the preprint in perpetuity.

It is made available under a CC-BY-NC-ND 4.0 International license .

835

836

837

838

839

840

841

842

843

844

845

846

847

848

849

850

851

852

853

854

855

856

68. Sdralis E, Argentou M, Mead N, Kehagias I, Alexandridis T, Kalfarentzos F. A Prospective

Randomized Study Comparing Patients with Morbid Obesity Submitted to Sleeve Gastrectomy

With or Without Omentectomy. Obesity Surgery. 2013;23(7):965-71. doi: 10.1007/s11695-0130925-z.

69. Beiglböck H, Fellinger P, Ranzenberger-Haider T, Itariu B, Prager G, Kautzky-Willer A, et al. Pre-operative Obesity-Associated Hyperandrogenemia in Women and Hypogonadism in Men Have No Impact on Weight Loss Following Bariatric Surgery. Obesity Surgery. 2020;30(10):394754. doi: $10.1007 / \mathrm{s} 11695-020-04761-4$.

70. Ernst B, Wilms B, Thurnheer M, Schultes B. Reduced circulating androgen levels after gastric bypass surgery in severely obese women. Obes Surg. 2013;23(5):602-7. Epub 2012/11/29. doi: 10.1007/s11695-012-0823-9. PubMed PMID: 23188476.

71. Bastounis EA, Karayiannakis AJ, Syrigos K, Zbar A, Makri GG, Alexiou D. Sex hormone changes in morbidly obese patients after vertical banded gastroplasty. Eur Surg Res. 1998;30(1):43-7. Epub 1998/03/11. doi: 10.1159/000008556. PubMed PMID: 9493693.

72. Dashti SG, English DR, Simpson JA, Karahalios A, Moreno-Betancur M, Biessy C, et al. Adiposity and Endometrial Cancer Risk in Postmenopausal Women: A Sequential Causal Mediation Analysis. Cancer Epidemiol Biomarkers Prev. 2021;30(1):104-13. Epub 2020/10/04. doi: 10.1158/1055-9965.Epi-20-0965. PubMed PMID: 33008875.

73. Pournaras DJ, Osborne A, Hawkins SC, Vincent RP, Mahon D, Ewings P, et al. Remission of type 2 diabetes after gastric bypass and banding: mechanisms and 2 year outcomes. Ann Surg. 2010;252(6):966-71. Epub 2010/11/26. doi: 10.1097/SLA.0b013e3181efc49a. PubMed PMID: 21107106. 
medRxiv preprint doi: https://doi.org/10.1101/2021.12.10.21267599; this version posted December 13 , 2021. The copyright holder for this preprint (which was not certified by peer review) is the author/funder, who has granted medRxiv a license to display the preprint in perpetuity.

It is made available under a CC-BY-NC-ND 4.0 International license.

857

858

859

860

861

862

863

864

865

866

867

868

869

870

871

872

873

874

875

876

877

878

74. ter Horst KW, Gilijamse PW, Koopman KE, de Weijer BA, Brands M, Kootte RS, et al.

Insulin resistance in obesity can be reliably identified from fasting plasma insulin. International Journal of Obesity. 2015;39(12):1703-9. doi: 10.1038/ijo.2015.125.

75. Brochu M, Mathieu M-E, Karelis AD, Doucet É, Lavoie M-E, Garrel D, et al. Contribution of the Lean Body Mass to Insulin Resistance in Postmenopausal Women With Visceral Obesity: A Monet Study. Obesity. 2008;16(5):1085-93. doi: https://doi.org/10.1038/oby.2008.23.

76. Trapp EG, Chisholm DJ, Freund J, Boutcher SH. The effects of high-intensity intermittent exercise training on fat loss and fasting insulin levels of young women. International Journal of Obesity. 2008;32(4):684-91. doi: 10.1038/sj.ijo.0803781.

77. Ross R, Janssen I, Dawson J, Kungl A-M, Kuk JL, Wong SL, et al. Exercise-Induced Reduction in Obesity and Insulin Resistance in Women: a Randomized Controlled Trial. Obesity Research. 2004;12(5):789-98. doi: https://doi.org/10.1038/oby.2004.95.

78. Wei S, Schmidt MD, Dwyer T, Norman RJ, Venn AJ. Obesity and Menstrual Irregularity: Associations With SHBG, Testosterone, and Insulin. Obesity. 2009;17(5):1070-6. doi:

https://doi.org/10.1038/oby.2008.641.

79. Tchernof A, Després J-P. Sex steroid hormones, sex hormone-binding globulin, and obesity in men and women. Hormone and Metabolic Research. 2000;32(11/12):526-36.

80. Henderson BE, Ross RK, Pike MC, Casagrande JT. Endogenous hormones as a major factor in human cancer. Cancer Res. 1982;42(8):3232-9. Epub 1982/08/01. PubMed PMID: 7046921.

81. Key TJ, Pike MC. The dose-effect relationship between 'unopposed' oestrogens and endometrial mitotic rate: its central role in explaining and predicting endometrial cancer risk. $\mathrm{Br}$ 
medRxiv preprint doi: https://doi.org/10.1101/2021.12.10.21267599; this version posted December 13 , 2021. The copyright holder for this preprint (which was not certified by peer review) is the author/funder, who has granted medRxiv a license to display the preprint in perpetuity.

It is made available under a CC-BY-NC-ND 4.0 International license .

879 J Cancer. 1988;57(2):205-12. Epub 1988/02/01. doi: 10.1038/bjc.1988.44. PubMed PMID:

880

881

882

883

884

885

886

887

888

889

890

891

892

893

894

895

896

897

898

899

900

3358913; PubMed Central PMCID: PMCPMC2246441.

82. Kaaks R, Lukanova A, Kurzer MS. Obesity, endogenous hormones, and endometrial cancer risk: a synthetic review. Cancer Epidemiol Biomarkers Prev. 2002;11(12):1531-43. Epub 2002/12/24. PubMed PMID: 12496040.

83. Bélanger $C$, Luu-The $V$, Dupont $P$, Tchernof A. Adipose tissue intracrinology: potential importance of local androgen/estrogen metabolism in the regulation of adiposity. Horm Metab Res. 2002;34(11-12):737-45. Epub 2003/03/28. doi: 10.1055/s-2002-38265. PubMed PMID: 12660892.

84. Somboonporn W, Davis SR. Testosterone Effects on the Breast: Implications for Testosterone Therapy for Women. Endocrine Reviews. 2004;25(3):374-88. doi:

10.1210/er.2003-0016.

85. Bulun SE, Lin Z, Imir G, Amin S, Demura M, Yilmaz B, et al. Regulation of Aromatase Expression in Estrogen-Responsive Breast and Uterine Disease: From Bench to Treatment. Pharmacological Reviews. 2005;57(3):359-83. doi: 10.1124/pr.57.3.6.

86. Simó R, Sáez-López C, Barbosa-Desongles A, Hernández C, Selva DM. Novel insights in SHBG regulation and clinical implications. Trends Endocrinol Metab. 2015;26(7):376-83. Epub 2015/06/06. doi: 10.1016/j.tem.2015.05.001. PubMed PMID: 26044465.

87. Grasa MDM, Gulfo J, Camps N, Alcalá R, Monserrat L, Moreno-Navarrete JM, et al. Modulation of SHBG binding to testosterone and estradiol by sex and morbid obesity. Eur J Endocrinol. 2017;176(4):393-404. Epub 2017/01/13. doi: 10.1530/eje-16-0834. PubMed PMID: 28077498. 
medRxiv preprint doi: https://doi.org/10.1101/2021.12.10.21267599; this version posted December 13 , 2021. The copyright holder for this preprint (which was not certified by peer review) is the author/funder, who has granted medRxiv a license to display the preprint in perpetuity.

It is made available under a CC-BY-NC-ND 4.0 International license .

901 88. Suba Z. Interplay between insulin resistance and estrogen deficiency as co- activators in

902

903

904

905

906

907

908

909

910

911

912

913

914

915

916

917

918

919

920

carcinogenesis. Pathol Oncol Res. 2012;18(2):123-33. Epub 2011/10/11. doi: 10.1007/s12253-

011-9466-8. PubMed PMID: 21984197.

89. Maturana MA, Spritzer PM. Association between hyperinsulinemia and endogenous

androgen levels in peri- and postmenopausal women. Metabolism. 2002;51(2):238-43. doi:

https://doi.org/10.1053/meta.2002.29997.

90. Weinberg ME, Manson JE, Buring JE, Cook NR, Seely EW, Ridker PM, et al. Low sex

hormone-binding globulin is associated with the metabolic syndrome in postmenopausal

women. Metabolism. 2006;55(11):1473-80. doi:

https://doi.org/10.1016/i.metabol.2006.06.017.

91. Mu N, Zhu $\mathrm{Y}$, Wang $\mathrm{Y}$, Zhang $\mathrm{H}$, Xue F. Insulin resistance: a significant risk factor of endometrial cancer. Gynecol Oncol. 2012;125(3):751-7. Epub 2012/03/28. doi:

10.1016/j.ygyno.2012.03.032. PubMed PMID: 22449736.

92. Haeusler RA, McGraw TE, Accili D. Biochemical and cellular properties of insulin receptor signalling. Nature Reviews Molecular Cell Biology. 2018;19(1):31-44. doi: 10.1038/nrm.2017.89. 93. Gunter MJ, Hoover DR, Yu H, Wassertheil-Smoller S, Manson JE, Li J, et al. A prospective evaluation of insulin and insulin-like growth factor-I as risk factors for endometrial cancer.

Cancer epidemiology, biomarkers \& prevention : a publication of the American Association for Cancer Research, cosponsored by the American Society of Preventive Oncology.

2008;17(4):921-9. doi: 10.1158/1055-9965.EPI-07-2686. PubMed PMID: 18398032. 
medRxiv preprint doi: https://doi.org/10.1101/2021.12.10.21267599; this version posted December 13 , 2021. The copyright holder for this preprint (which was not certified by peer review) is the author/funder, who has granted medRxiv a license to display the preprint in perpetuity.

It is made available under a CC-BY-NC-ND 4.0 International license .

921

922

923

924

925

926

927

928

929

930

931

932

933

934

935

936

937

938

939

940

94. Ogawa K, Sun C, Horii A. Exploration of genetic alterations in human endometrial cancer and melanoma: distinct tumorigenic pathways that share a frequent abnormal PI3K/AKT cascade. Oncol Rep. 2005;14(6):1481-5. Epub 2005/11/08. PubMed PMID: 16273242.

95. Slomovitz BM, Coleman RL. The PI3K/AKT/mTOR pathway as a therapeutic target in endometrial cancer. Clin Cancer Res. 2012;18(21):5856-64. Epub 2012/10/20. doi:

10.1158/1078-0432.Ccr-12-0662. PubMed PMID: 23082003.

96. Weigelt B, Warne PH, Lambros MB, Reis-Filho JS, Downward J. PI3K Pathway

Dependencies in Endometrioid Endometrial Cancer Cell Lines. Clinical Cancer Research.

2013;19(13):3533-44. doi: 10.1158/1078-0432.Ccr-12-3815.

97. Phillips AN, Smith GD. How independent are "independen" effects? relative risk estimation when correlated exposures are measured imprecisely. Journal of Clinical Epidemiology. 1991;44(11):1223-31. doi: 10.1016/0895-4356(91)90155-3.

98. Subramaniam KS, Tham ST, Mohamed Z, Woo YL, Mat Adenan NA, Chung I. Cancerassociated fibroblasts promote proliferation of endometrial cancer cells. PLoS One.

2013;8(7):e68923. Epub 2013/08/08. doi: 10.1371/journal.pone.0068923. PubMed PMID: 23922669; PubMed Central PMCID: PMCPMC3724864.

99. Subramaniam KS, Omar IS, Kwong SC, Mohamed Z, Woo YL, Mat Adenan NA, et al. Cancer-associated fibroblasts promote endometrial cancer growth via activation of interleukin6/STAT-3/c-Myc pathway. Am J Cancer Res. 2016;6(2):200-13. Epub 2016/05/18. PubMed PMID: 27186396; PubMed Central PMCID: PMCPMC4859653. 
medRxiv preprint doi: https://doi.org/10.1101/2021.12.10.21267599; this version posted December 13 , 2021. The copyright holder for this preprint (which was not certified by peer review) is the author/funder, who has granted medRxiv a license to display the preprint in perpetuity.

It is made available under a CC-BY-NC-ND 4.0 International license .

941

942

943

944

945

946

947

948

949

950

951

952

953

954

955

956

957

958

959

960

961

962

100. Renehan AG, Soerjomataram I, Tyson M, Egger M, Zwahlen M, Coebergh JW, et al.

Incident cancer burden attributable to excess body mass index in 30 European countries.

International Journal of Cancer. 2010;126(3):692-702. doi: https://doi.org/10.1002/iic.24803.

101. Ochner CN, Tsai AG, Kushner RF, Wadden TA. Treating obesity seriously: when

recommendations for lifestyle change confront biological adaptations. The Lancet Diabetes \&

Endocrinology. 2015;3(4):232-4. doi: 10.1016/S2213-8587(15)00009-1.

102. Evert AB, Franz MJ. Why Weight Loss Maintenance Is Difficult. Diabetes Spectrum.

2017;30(3):153-6. doi: 10.2337/ds017-0025.

103. Abarca-Gómez L, Abdeen ZA, Hamid ZA, Abu-Rmeileh NM, Acosta-Cazares B, Acuin C, et

al. Worldwide trends in body-mass index, underweight, overweight, and obesity from 1975 to

2016: a pooled analysis of 2416 population-based measurement studies in $128 \& \# \times b 7 ; 9$ million

children, adolescents, and adults. The Lancet. 2017;390(10113):2627-42. doi: 10.1016/S0140-

6736(17)32129-3.

104. Wang Y, Beydoun MA, Min J, Xue H, Kaminsky LA, Cheskin L. Has the prevalence of overweight, obesity and central obesity levelled off in the United States? Trends, patterns, disparities, and future projections for the obesity epidemic. International Journal of

Epidemiology. 2020;49(3):810-23. doi: 10.1093/ije/dyz273.

105. Pineda E, Sanchez-Romero LM, Brown M, Jaccard A, Jewell J, Galea G, et al. Forecasting

Future Trends in Obesity across Europe: The Value of Improving Surveillance. Obesity Facts.

2018;11(5):360-71. doi: 10.1159/000492115.

106. Zhou G, Myers R, Li Y, Chen Y, Shen X, Fenyk-Melody J, et al. Role of AMP-activated protein kinase in mechanism of metformin action. J Clin Invest. 2001;108(8):1167-74. Epub 
medRxiv preprint doi: https://doi.org/10.1101/2021.12.10.21267599; this version posted December 13, 2021. The copyright holder for this preprint (which was not certified by peer review) is the author/funder, who has granted medRxiv a license to display the preprint in perpetuity.

It is made available under a CC-BY-NC-ND 4.0 International license .

963

964

965

966

967

968

969

970

971

972

973

974

975

976

977

978

979

980

981

982

983

984

2001/10/17. doi: 10.1172/jci13505. PubMed PMID: 11602624; PubMed Central PMCID:

PMCPMC209533.

107. Knowler WC, Fowler SE, Hamman RF, Christophi CA, Hoffman HJ, Brenneman AT, et al.

10-year follow-up of diabetes incidence and weight loss in the Diabetes Prevention Program

Outcomes Study. Lancet. 2009;374(9702):1677-86. Epub 2009/11/03. doi: 10.1016/s0140-

6736(09)61457-4. PubMed PMID: 19878986; PubMed Central PMCID: PMCPMC3135022.

108. Boccardo F, Guarneri D, Rubagotti A, Casertelli GL, Bentivoglio G, Conte N, et al.

Endocrine effects of tamoxifen in postmenopausal breast cancer patients. Tumori.

1984;70(1):61-8. Epub 1984/02/29. PubMed PMID: 6538707.

109. Hu R, Hilakivi-Clarke L, Clarke R. Molecular mechanisms of tamoxifen-associated

endometrial cancer (Review). Oncol Lett. 2015;9(4):1495-501. Epub 2015/03/20. doi:

10.3892/ol.2015.2962. PubMed PMID: 25788989; PubMed Central PMCID: PMCPMC4356269.

110. Fleming CA, Heneghan HM, O'Brien D, McCartan DP, McDermott EW, Prichard RS. Meta-

analysis of the cumulative risk of endometrial malignancy and systematic review of endometrial

surveillance in extended tamoxifen therapy. British Journal of Surgery. 2018;105(9):1098-106. doi: 10.1002/bjs.10899.

111. Berruti A, Terzolo M, Pia A, Angeli A, Dogliotti L. Mitotane associated with etoposide, doxorubicin, and cisplatin in the treatment of advanced adrenocortical carcinoma. Cancer. 1998;83(10):2194-200. doi: https://doi.org/10.1002/(SICI)1097-

0142(19981115)83:10<2194::AID-CNCR19>3.0.CO;2-3.

112. Theile $D$, Haefeli WE, Weiss J. Effects of adrenolytic mitotane on drug elimination pathways assessed in vitro. Endocrine. 2015;49(3):842-53. doi: 10.1007/s12020-014-0517-2. 
medRxiv preprint doi: https://doi.org/10.1101/2021.12.10.21267599; this version posted December 13 , 2021. The copyright holder for this preprint (which was not certified by peer review) is the author/funder, who has granted medRxiv a license to display the preprint in perpetuity.

It is made available under a CC-BY-NC-ND 4.0 International license .

985

986

987

988

989

990

991

992

993

994

995

996

997

998

999

1000

1001

1002

1003

1004

1005

113. Farland LV, Mu F, Eliassen AH, Hankinson SE, Tworoger SS, Barbieri RL, et al. Menstrual cycle characteristics and steroid hormone, prolactin, and growth factor levels in premenopausal women. Cancer Causes Control. 2017;28(12):1441-52. Epub 2017/11/01. doi: 10.1007/s10552-

017-0971-2. PubMed PMID: 29086892; PubMed Central PMCID: PMCPMC5718047.

114. Janda M, Robledo KP, Gebski V, Armes JE, Alizart M, Cummings M, et al. Complete pathological response following levonorgestrel intrauterine device in clinically stage 1 endometrial adenocarcinoma: Results of a randomized clinical trial. Gynecologic Oncology. 2021;161(1):143-51. doi: https://doi.org/10.1016/i.ygyno.2021.01.029.

115. Barr CE, Ryan NAJ, Derbyshire AE, Wan YL, MacKintosh ML, McVey RJ, et al. Weight Loss During Intrauterine Progestin Treatment for Obesity-associated Atypical Hyperplasia and EarlyStage Cancer of The Endometrium. Cancer Prev Res (Phila). 2021;14(11):1041-50. Epub 2021/08/06. doi: 10.1158/1940-6207.Capr-21-0229. PubMed PMID: 34348914.

116. Lagou V, Mägi R, Hottenga J-J, Grallert H, Perry JRB, Bouatia-Naji N, et al. Sex-dimorphic genetic effects and novel loci for fasting glucose and insulin variability. Nature Communications. 2021;12(1):24. doi: 10.1038/s41467-020-19366-9.

117. Chen J, Spracklen CN, Marenne G, Varshney A, Corbin L, Luan Ja, et al. The transancestral genomic architecture of glycemic traits. Nature Genetics. 2021;53(6):840-60. doi: 10.1038/s41588-021-00852-9.

118. Larsson SC, Carter P, Vithayathil M, Kar S, Mason AM, Burgess S. Insulin-like growth factor-1 and site-specific cancers: A Mendelian randomization study. Cancer Medicine. 2020;9(18):6836-42. doi: https://doi.org/10.1002/cam4.3345. 
medRxiv preprint doi: https://doi.org/10.1101/2021.12.10.21267599; this version posted December 13, 2021. The copyright holder for this preprint (which was not certified by peer review) is the author/funder, who has granted medRxiv a license to display the preprint in perpetuity.

It is made available under a CC-BY-NC-ND 4.0 International license .

1006 119. Locke AE, Steinberg KM, Chiang CWK, Service SK, Havulinna AS, Stell L, et al. Exome 1007 sequencing of Finnish isolates enhances rare-variant association power. Nature.

1008 2019;572(7769):323-8. Epub 2019/07/31. doi: 10.1038/s41586-019-1457-z. PubMed PMID:

100931367044.

1010 120. Folkersen L, Gustafsson S, Wang Q, Hansen DH, Hedman ÅK, Schork A, et al. Genomic 1011 evaluation of circulating proteins for drug target characterisation and precision medicine.

1012 bioRxiv. 2020:2020.04.03.023804. doi: 10.1101/2020.04.03.023804.

1013 121. C Reactive Protein Coronary Heart Disease Genetics Collaboration (CCGC). Association

1014 between $\mathrm{C}$ reactive protein and coronary heart disease: mendelian randomisation analysis

1015 based on individual participant data. BMJ. 2011;342:d548. doi: 10.1136/bmj.d548.

1016 
medRxiv preprint doi: https://doi.org/10.1101/2021.12.10.21267599; this version posted December 13, 2021. The copyright holder for this preprint (which was not certified by peer review) is the author/funder, who has granted medRxiv a license to display the preprint in perpetuity.

It is made available under a CC-BY-NC-ND 4.0 International license .

1017

1018

1019

1020

1021

1022

1023

1024

1025

1026

1027

1028

1029

1030

1031

1032

1033

1034

1035

1036

1037

1038

1039

1040

Figure Legends:

Fig 1. Flowchart detailing the process of identifying previously reported risk factors with suitable genetic instruments.

TNF- $\alpha$ = tumour necrosis factor- $\alpha$, IGFBP-1 = insulin-like growth factor-binding protein-1, LDL = lowdensity lipoprotein, HDL = high-density lipoprotein, IGF-1 = insulin-like growth factor-1, IL-6 = interleukin-6, CRP = C-reactive protein, SHBG = sex hormone-binding globulin.

\section{Fig 2. DAG demonstrating the core assumptions of Mendelian randomization.}

$D A G=$ directed acyclic diagram, $G=$ genetic instrument, $E=$ exposure, $\mathrm{O}=$ outcome, $\mathrm{C}=$ confounding factors. Arrows labelled 1, 2, and 3 represent the three core assumptions of MR: (1) the instrument strongly associates with the exposure ("relevance"); (2) there is no confounding of the instrumentoutcome relationship ("exchangeability"); and (3) the instrument only affects the outcome through the exposure ("exclusion restriction"). MR uses genetic instruments to proxy exposures in order to strengthen causal inference in observational epidemiological settings. As these genetic instruments are randomly inherited at meiosis, they should not be affected by conventional confounding factors like environmental, lifestyle, and behavioural traits. In addition, since germline genetic variants are fixed at conception and cannot be altered by subsequent exposures, they are not susceptible to reverse causation. Finally, germline genotype can be measured relatively precisely using modern genotyping technologies which minimises measurement error. Collectively, these properties of germline genetic variants (along with technologies that measure them) permit MR analyses to minimise many of the sources of bias which can undermine robust causal inference in conventional observational epidemiological analyses. 
medRxiv preprint doi: https://doi.org/10.1101/2021.12.10.21267599; this version posted December 13, 2021. The copyright holder for this preprint (which was not certified by peer review) is the author/funder, who has granted medRxiv a license to display the preprint in perpetuity.

It is made available under a CC-BY-NC-ND 4.0 International license .

1041

1042

1043

1044

1045

1046

1047

1048

1049

1050

1051

1052

1053

1054

1055

1056

1057

1058

1059

1060

1061
Fig 3. DAG demonstrating the proposed causal interactions of BMI, SHBG, fasting insulin, and bioavailable testosterone on endometrial cancer (overall and the endometrioid histological subtype). $\mathrm{DAG}=$ directed acyclic diagram, $\mathrm{BMI}=$ body mass index, $\mathrm{SHBG}=$ sex hormone-binding globulin.

Fig 4. Mendelian randomization analysis of BMI on overall and subtype-specific endometrial cancer risk.

Results of MR analyses examining the effect of adult BMI on risk of overall and subtype-specific endometrial cancer risk.

Fig 5. Mendelian randomization analysis of total serum cholesterol, fasting insulin, total testosterone, bioavailable testosterone, and sex hormone-binding globulin (SHBG) on overall and endometrioid endometrial cancer risk.

$\mathrm{LDL}=$ low-density lipoprotein, $\mathrm{HDL}=$ high-density lipoprotein, IGF-1 = insulin-like growth factor-1, IL-6 = interleukin-6, CRP = C-reactive protein, SHBG = sex hormone-binding globulin. (A) Results of MR analyses examining the effects of previously reported molecular risk factors on risk of overall endometrial cancer risk. (B) Results of MR analyses examining the effects of previously reported molecular risk factors on risk of endometrioid subtype endometrial cancer risk.

Fig 6. Mendelian randomization analysis of adult BMI on previously reported endometrial cancer risk factors.

SHBG = sex hormone-binding globulin, $\mathrm{LDL}=$ low-density lipoprotein, $\mathrm{CRP}=\mathrm{C}$-reactive protein . 
medRxiv preprint doi: https://doi.org/10.1101/2021.12.10.21267599; this version posted December 13, 2021. The copyright holder for this preprint (which was not certified by peer review) is the author/funder, who has granted medRxiv a license to display the preprint in perpetuity.

It is made available under a CC-BY-NC-ND 4.0 International license .

1062 Table 1. Details of the instruments used for exposures.

\begin{tabular}{|c|c|c|c|c|c|c|}
\hline Exposure & GWAS & Sample size & Number of SNPs & $\mathbf{R}^{2}$ & F-statistic & Sex-specificity \\
\hline Adult BMI & Yengo et al. [42] & 681,275 & 507 & 0.078 & 57,847 & Combined \\
\hline LDL-cholesterol & Willer et al. [34] & 188,577 & 81 & 0.182 & 15,002 & Combined \\
\hline HDL-cholesterol & Willer et al. [34] & 188,577 & 89 & 0.055 & 10,978 & Combined \\
\hline Triglyceride & Willer et al. [34] & 188,577 & 55 & 0.052 & 9,811 & Combined \\
\hline $\begin{array}{l}\text { Total serum } \\
\text { cholesterol }\end{array}$ & Willer et al. [34] & 188,577 & 88 & 0.063 & 12,696 & Combined \\
\hline Glucose & Neale et al. [36] & 361,194 & 109 & 0.036 & 11,776 & Female \\
\hline $\begin{array}{l}\text { Fasting insulin } \\
\text { (unadjusted for }\end{array}$ & Lagou et al. [116] & 98,210 & 14 & 0.005 & 523 & Combined \\
\hline BMI) & & & & & & \\
\hline $\begin{array}{l}\text { Fasting insulin } \\
\text { (adjusted for } \\
\text { BMI) }\end{array}$ & Chen et al. [117] & 150,571 & 14 & 0.006 & 865 & Combined \\
\hline $\begin{array}{l}\text { IGF-1 (cis and } \\
\text { trans variants) }\end{array}$ & $\begin{array}{c}\text { Sinnott-Armstrong } \\
\text { et al. [37] }\end{array}$ & 358,072 & 413 & 0.036 & 13,367 & Combined \\
\hline IGF-1 (cis & Larsson et al. & 358,072 & 1 & 0.002 & 814 & Combined \\
\hline variants) & [118] & & & & & \\
\hline
\end{tabular}


medRxiv preprint doi: https://doi.org/10.1101/2021.12.10.21267599; this version posted December 13, 2021. The copyright holder for this preprint (which was not certified by peer review) is the author/funder, who has granted medRxiv a license to display the preprint in perpetuity. It is made available under a CC-BY-NC-ND 4.0 International license .

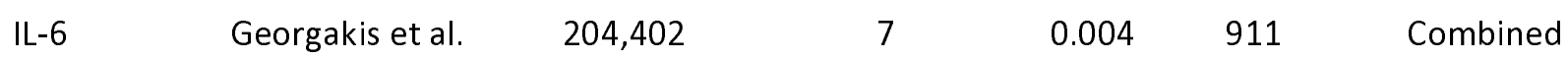
[38]

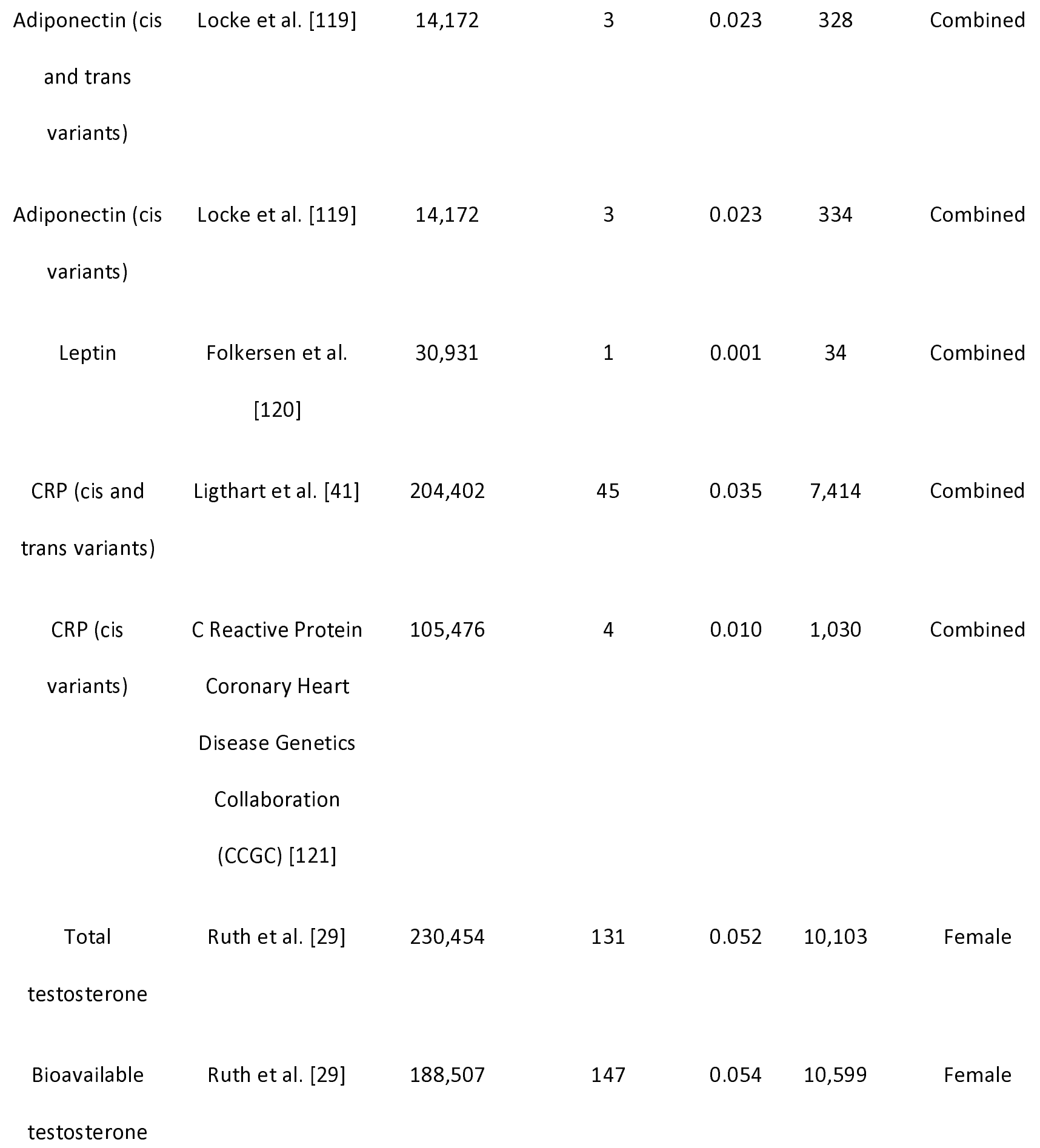


medRxiv preprint doi: https://doi.org/10.1101/2021.12.10.21267599; this version posted December 13, 2021. The copyright holder for this preprint (which was not certified by peer review) is the author/funder, who has granted medRxiv a license to display the preprint in perpetuity. It is made available under a CC-BY-NC-ND 4.0 International license .
SHBG
Ruth et al. [29]
189,473
215
$0.122 \quad 26,286$
Female

1063

1064

1065

1066

1067

1068

1069

1070

1071

1072
BMI is scaled to an SD increase $\left(4.7 \mathrm{~kg} / \mathrm{m}^{2}\right)$. For the analysis involving the plasma proteome, due to the requirement of increased statistical power in order to overcome the multiple testing burden, alternative summary genetic association data for BMI were obtained from a genome-wide association study of 681,275 individuals of European ancestry (note that this summary genetic data could not be used for other analyses due to substantial overlap of participants with summary genetic data of other traits) [42]. The CRP GWAS included some individuals of non-European ancestry and adjusted for ancestry where applicable. $\mathrm{BMI}=$ body mass index, LDL = low-density lipoprotein, $\mathrm{HDL}=$ high density lipoprotein, IGF-1 = Insulin-like growth factor-1, IL-6 = interleukin-6, CRP = C-reactive protein, SHBG = sex hormone-binding globulin, LD = linkage disequilibrium. For instrument construction of IGF-1 (cis and trans variants), a $P$ value of $5 \times 10^{-6}$ was used. 
medRxiv preprint doi: https://doi.org/10.1101/2021.12.10.21267599; this version posted December 13, 2021. The copyright holder for this preprint (which was not certified by peer review) is the author/funder, who has granted medRxiv a license to display the preprint in perpetuity.

It is made available under a CC-BY-NC-ND 4.0 International license.

1073 Table 2. Results of MR analyses examining the effect of adult BMI on risk of overall and subtype-

1074 specific endometrial cancer risk

\begin{tabular}{|c|c|c|c|}
\hline Outcome & Method & OR $(95 \% \mathrm{CI})$ & $P$ value \\
\hline Overall & IVW & 1.88 (1.69 to 2.09$)$ & $3.87 \times 10^{-31}$ \\
\hline endometrial & Weighted median & 1.89 (1.58 to 2.26$)$ & $5.18 \times 10^{-12}$ \\
\hline \multirow[t]{2}{*}{ cancer } & Weighted mode & $1.82(1.35$ to 2.44$)$ & $9.88 \times 10^{-5}$ \\
\hline & MR Egger & $2.03(1.54$ to 2.67$)$ & $8.41 \times 10^{-7}$ \\
\hline Endometrioid & IVW & 1.89 (1.65 to 2.16$)$ & $1.67 \times 10^{-20}$ \\
\hline endometrial & Weighted median & 1.99 (1.60 to 2.46$)$ & $3.24 \times 10^{-10}$ \\
\hline \multirow[t]{2}{*}{ cancer } & Weighted mode & 1.96 (1.42 to 2.69$)$ & $4.67 \times 10^{-5}$ \\
\hline & MR Egger & $2.15(1.52$ to 3.03$)$ & $1.74 \times 10^{-5}$ \\
\hline Non-endometrioid & IVW & $1.67(1.19$ to 2.35$)$ & $3.03 \times 10^{-3}$ \\
\hline endometrial & Weighted median & 2.29 (1.24 to 4.22$)$ & $8.24 \times 10^{-3}$ \\
\hline \multirow[t]{2}{*}{ cancer } & Weighted mode & $1.89(0.77$ to 4.63$)$ & $1.63 \times 10^{-1}$ \\
\hline & MR Egger & 2.25 (0.99 to 5.07$)$ & $5.28 \times 10^{-2}$ \\
\hline
\end{tabular}

1075

ORs are shown per increase in $\mathrm{SD}\left(4.7 \mathrm{~kg} / \mathrm{m}^{2}\right) \mathrm{BMI} . \mathrm{BMI}=$ body mass index, IVW = inverse-variance

1076 weighted.

1077 
medRxiv preprint doi: https://doi.org/10.1101/2021.12.10.21267599; this version posted December 13, 2021. The copyright holder for this preprint (which was not certified by peer review) is the author/funder, who has granted medRxiv a license to display the preprint in perpetuity.

It is made available under a CC-BY-NC-ND 4.0 International license.

1078 Table 3. Results of MR analyses examining the effect of previously reported and novel potential

1079 molecular risk factors and overall and endometrioid subtype endometrial cancer risk.

\begin{tabular}{|c|c|c|c|c|}
\hline Exposure & Outcome & Method & OR $(95 \% \mathrm{Cl})$ & $P$ value \\
\hline LDL- & Overall endometrial cancer & IVW & $0.95(0.87$ to 1.04$)$ & $3.05 \times 10^{-1}$ \\
\hline \multirow[t]{7}{*}{ cholesterol } & & Weighted median & $0.92(0.82$ to 1.03$)$ & $1.31 \times 10^{-1}$ \\
\hline & & Weighted mode & 0.91 (0.82 to 1.02$)$ & $9.54 \times 10^{-2}$ \\
\hline & & MR Egger & 0.90 (0.79 to 1.03$)$ & $1.35 \times 10^{-1}$ \\
\hline & Endometrioid endometrial cancer & IVW & $0.98(0.89$ to 1.08$)$ & $6.70 \times 10^{-1}$ \\
\hline & & Weighted median & $0.96(0.84$ to 1.10$)$ & $5.61 \times 10^{-1}$ \\
\hline & & Weighted mode & $0.93(0.83$ to 1.06$)$ & $2.79 \times 10^{-1}$ \\
\hline & & MR Egger & 0.93 (0.81 to 1.07$)$ & $3.31 \times 10^{-1}$ \\
\hline HDL- & Overall endometrial cancer & IVW & $1.09(0.97$ to 1.23$)$ & $1.48 \times 10^{-1}$ \\
\hline \multirow[t]{7}{*}{ cholesterol } & & Weighted median & $1.10(0.96$ to 1.26$)$ & $1.89 \times 10^{-1}$ \\
\hline & & Weighted mode & $1.07(0.94$ to 1.23$)$ & $3.11 \times 10^{-1}$ \\
\hline & & MR Egger & $1.08(0.86$ to 1.35$)$ & $4.99 \times 10^{-1}$ \\
\hline & Endometrioid endometrial cancer & IVW & 1.04 (0.90 to 1.19$)$ & $6.05 \times 10^{-1}$ \\
\hline & & Weighted median & $0.99(0.84$ to 1.16$)$ & $8.76 \times 10^{-1}$ \\
\hline & & Weighted mode & $1.03(0.88$ to 1.21$)$ & $7.23 \times 10^{-1}$ \\
\hline & & MR Egger & $0.92(0.71$ to 1.20$)$ & $5.61 \times 10^{-1}$ \\
\hline \multirow[t]{5}{*}{ Triglyceride } & Overall endometrial cancer & IVW & $0.95(0.84$ to 1.06$)$ & $3.55 \times 10^{-1}$ \\
\hline & & Weighted median & $0.87(0.75$ to 1.01$)$ & $7.75 \times 10^{-2}$ \\
\hline & & Weighted mode & $0.91(0.79$ to 1.04$)$ & $1.61 \times 10^{-1}$ \\
\hline & & MR Egger & $0.83(0.69$ to 1.00$)$ & $6.03 \times 10^{-2}$ \\
\hline & Endometrioid endometrial cancer & IVW & 0.95 (0.83 to 1.09$)$ & $4.65 \times 10^{-1}$ \\
\hline
\end{tabular}


medRxiv preprint doi: https://doi.org/10.1101/2021.12.10.21267599; this version posted December 13, 2021. The copyright holder for this preprint (which was not certified by peer review) is the author/funder, who has granted medRxiv a license to display the preprint in perpetuity. It is made available under a CC-BY-NC-ND 4.0 International license.

\begin{tabular}{|c|c|c|c|c|}
\hline Total serum & Overall endometrial cancer & IVW & $0.90(0.81$ to 1.00$)$ & $4.01 \times 10^{-2}$ \\
\hline \multirow[t]{7}{*}{ cholesterol } & & Weighted median & $0.80(0.71$ to 0.90$)$ & $2.08 \times 10^{-4}$ \\
\hline & & Weighted mode & $0.82(0.73$ to 0.91$)$ & $5.97 \times 10^{-4}$ \\
\hline & & MR Egger & 0.84 (0.71 to 0.98$)$ & $3.09 \times 10^{-2}$ \\
\hline & Endometrioid endometrial cancer & IVW & $0.91(0.82$ to 1.02$)$ & $9.31 \times 10^{-2}$ \\
\hline & & Weighted median & 0.81 (0.71 to 0.93$)$ & $3.40 \times 10^{-3}$ \\
\hline & & Weighted mode & $0.84(0.74$ to 0.97$)$ & $1.64 \times 10^{-2}$ \\
\hline & & MR Egger & $0.86(0.72$ to 1.01$)$ & $7.60 \times 10^{-2}$ \\
\hline \multirow[t]{8}{*}{ Glucose } & Overall endometrial cancer & IVW & $0.95(0.79$ to 1.14$)$ & $5.64 \times 10^{-1}$ \\
\hline & & Weighted median & 0.97 (0.80 to 1.17$)$ & $7.36 \times 10^{-1}$ \\
\hline & & Weighted mode & 0.93 (0.78 to 1.11$)$ & $4.47 \times 10^{-1}$ \\
\hline & & MR Egger & $0.99(0.73$ to 1.34$)$ & $9.29 \times 10^{-1}$ \\
\hline & Endometrioid endometrial cancer & IVW & $0.90(0.73$ to 1.11$)$ & $3.26 \times 10^{-1}$ \\
\hline & & Weighted median & $0.98(0.77$ to 1.23$)$ & $8.31 \times 10^{-1}$ \\
\hline & & Weighted mode & $0.98(0.80$ to 1.20$)$ & $8.29 \times 10^{-1}$ \\
\hline & & MR Egger & 0.94 (0.67 to 1.33$)$ & $7.39 \times 10^{-1}$ \\
\hline Fasting & Overall endometrial cancer & IVW & $3.93(2.29$ to 6.74$)$ & $7.18 \times 10^{-7}$ \\
\hline \multirow[t]{4}{*}{ insulin } & & Weighted median & 3.49 (1.60 to 7.62$)$ & $1.67 \times 10^{-3}$ \\
\hline & & Weighted mode & 3.55 (0.85 to 14.78$)$ & $1.06 \times 10^{-1}$ \\
\hline & & MR Egger & $8.28(0.67$ to 102.10$)$ & $1.25 \times 10^{-1}$ \\
\hline & Endometrioid endometrial cancer & IVW & 4.64 (2.30 to 9.36$)$ & $1.84 \times 10^{-5}$ \\
\hline
\end{tabular}


medRxiv preprint doi: https://doi.org/10.1101/2021.12.10.21267599; this version posted December 13, 2021. The copyright holder for this preprint (which was not certified by peer review) is the author/funder, who has granted medRxiv a license to display the preprint in perpetuity.

It is made available under a CC-BY-NC-ND 4.0 International license .

\begin{tabular}{|c|c|c|c|c|}
\hline IGF-1 (cis and & Overall endometrial cancer & IVW & $0.93(0.85$ to 1.06$)$ & $2.60 \times 10^{-1}$ \\
\hline trans & & Weighted median & 1.01 (0.85 to 1.20$)$ & $8.96 \times 10^{-1}$ \\
\hline \multirow[t]{6}{*}{ variants) } & & Weighted mode & $1.22(0.89$ to 1.67$)$ & $2.28 \times 10^{-1}$ \\
\hline & & MR Egger & $1.17(0.85$ to 1.60$)$ & $3.49 \times 10^{-1}$ \\
\hline & Endometrioid endometrial cancer & IVW & 0.89 (0.77 to 1.03$)$ & $1.12 \times 10^{-1}$ \\
\hline & & Weighted median & $1.03(0.84$ to 1.25$)$ & $8.06 \times 10^{-1}$ \\
\hline & & Weighted mode & $1.32(0.92$ to 1.90$)$ & $1.30 \times 10^{-1}$ \\
\hline & & MR Egger & $1.22(0.85$ to 1.76$)$ & $2.75 \times 10^{-1}$ \\
\hline IGF-1 (cis & Overall endometrial cancer & Wald ratio & $1.20(0.79$ to 1.82$)$ & $3.92 \times 10^{-1}$ \\
\hline variants) & Endometrioid endometrial cancer & Wald ratio & $1.40(0.85$ to 2.28$)$ & $1.84 \times 10^{-1}$ \\
\hline IL-6 (scaled & Overall endometrial cancer & IVW & $0.90(0.66$ to 1.21$)$ & $4.80 \times 10^{-1}$ \\
\hline to natural log & Endometrioid endometrial cancer & IVW & 0.86 (0.60 to 1.23$)$ & $4.01 \times 10^{-1}$ \\
\hline \multicolumn{5}{|l|}{ transformed } \\
\hline \multicolumn{5}{|l|}{$\mathrm{mg} / \mathrm{L}$ change } \\
\hline \multicolumn{5}{|l|}{ in (RP) } \\
\hline Adiponectin & Overall endometrial cancer & IVW & $0.92(0.79$ to 1.08$)$ & $3.17 \times 10^{-1}$ \\
\hline (cis and trans & Endometrioid endometrial cancer & IVW & $0.94(0.78$ to 1.13$)$ & $4.99 \times 10^{-1}$ \\
\hline \multicolumn{5}{|l|}{ variants) } \\
\hline Adiponectin & Overall endometrial cancer & IVW & 0.95 (0.83 to 1.08$)$ & $3.94 \times 10^{-1}$ \\
\hline (cis variants) & Endometrioid endometrial cancer & IVW & 1.00 (0.86 to 1.16$)$ & $9.92 \times 10^{-1}$ \\
\hline Leptin & Overall endometrial cancer & Wald Ratio & 1.03 (0.68 to 1.54$)$ & $8.96 \times 10^{-1}$ \\
\hline
\end{tabular}

$\begin{array}{ccc}\text { Weighted median } & 3.93(1.56 \text { to } 9.93) & 3.80 \times 10^{-3} \\ \text { Weighted mode } & 3.28(0.69 \text { to } 15.62) & 1.61 \times 10^{-1} \\ \text { MR Egger } & 21.59(0.78 \text { to } 593.93) & 9.66 \times 10^{-2}\end{array}$

IVW

$0.93(0.85$ to 1.06$) \quad 2.60 \times 10^{-1}$

Weighted median $1.01(0.85$ to 1.20$) \quad 8.96 \times 10^{-1}$

Weighted mode $\quad 1.22(0.89$ to 1.67$) \quad 2.28 \times 10^{-1}$

MR Egger $\quad 1.17(0.85$ to 1.60$) \quad 3.49 \times 10^{-1}$

IVW $\quad 0.89(0.77$ to 1.03$) \quad 1.12 \times 10^{-1}$

Weighted median $\quad 1.03(0.84$ to 1.25$) \quad 8.06 \times 10^{-1}$

Weighted mode $\quad 1.32(0.92$ to 1.90$) \quad 1.30 \times 10^{-1}$

MR Egger $\quad 1.22(0.85$ to 1.76$) \quad 2.75 \times 10^{-1}$

Wald ratio $\quad 1.20(0.79$ to 1.82$) \quad 3.92 \times 10^{-1}$

Wald ratio $\quad 1.40(0.85$ to 2.28$) \quad 1.84 \times 10^{-1}$

IVW $\quad 0.90(0.66$ to 1.21$) \quad 4.80 \times 10^{-1}$

IVW $\quad 0.86(0.60$ to 1.23$) \quad 4.01 \times 10^{-1}$

to natural log Endometrioid endometrial cancer

Wald Ratio

$8.96 \times 10^{-1}$ 
medRxiv preprint doi: https://doi.org/10.1101/2021.12.10.21267599; this version posted December 13, 2021. The copyright holder for this preprint (which was not certified by peer review) is the author/funder, who has granted medRxiv a license to display the preprint in perpetuity.

It is made available under a CC-BY-NC-ND 4.0 International license .

\begin{tabular}{|c|c|c|c|c|}
\hline & Endometrioid endometrial cancer & Wald Ratio & $0.88(0.54$ to 1.42$)$ & $5.99 \times 10^{-1}$ \\
\hline CRP (cis and & Overall endometrial cancer & IVW & $1.07(0.94$ to 1.22$)$ & $3.03 \times 10^{-1}$ \\
\hline trans & & Weighted median & $0.97(0.84$ to 1.12$)$ & $6.76 \times 10^{-1}$ \\
\hline \multirow[t]{6}{*}{ variants) } & & Weighted mode & $1.02(0.91$ to 1.14$)$ & $7.80 \times 10^{-1}$ \\
\hline & & MR Egger & $0.96(0.80$ to 1.16$)$ & $6.99 \times 10^{-1}$ \\
\hline & Endometrioid endometrial cancer & IVW & $1.12(0.96$ to 1.30$)$ & $1.39 \times 10^{-1}$ \\
\hline & & Weighted median & $1.03(0.87$ to 1.23$)$ & $6.92 \times 10^{-1}$ \\
\hline & & Weighted mode & $1.04(0.90$ to 1.20$)$ & $6.34 \times 10^{-1}$ \\
\hline & & MR Egger & $0.97(0.78$ to 1.20$)$ & $7.69 \times 10^{-1}$ \\
\hline CRP (cis & Overall endometrial cancer & IVW & $0.98(0.85$ to 1.13$)$ & $7.52 \times 10^{-1}$ \\
\hline variants) & Endometrioid endometrial cancer & IVW & $0.98(0.83$ to 1.16$)$ & $8.02 \times 10^{-1}$ \\
\hline Total & Overall endometrial cancer & IVW & $1.64(1.43$ to 1.88$)$ & $1.71 \times 10^{-12}$ \\
\hline \multirow[t]{7}{*}{ testosterone } & & Weighted median & $1.67(1.39$ to 2.01$)$ & $3.95 \times 10^{-8}$ \\
\hline & & Weighted mode & $1.74(1.38$ to 2.20$)$ & $8.33 \times 10^{-6}$ \\
\hline & & MR Egger & 1.81 (1.38 to 2.38$)$ & $4.17 \times 10^{-5}$ \\
\hline & Endometrioid endometrial cancer & IVW & $1.60(1.36$ to 1.87$)$ & $8.70 \times 10^{-9}$ \\
\hline & & Weighted median & $1.81(1.45$ to 2.26$)$ & $2.05 \times 10^{-7}$ \\
\hline & & Weighted mode & $1.88(1.42$ to 2.48$)$ & $2.34 \times 10^{-5}$ \\
\hline & & MR Egger & $1.74(1.26$ to 2.41$)$ & $1.02 \times 10^{-3}$ \\
\hline Bioavailable & Overall endometrial cancer & IVW & $1.46(1.29$ to 1.65$)$ & $3.48 \times 10^{-9}$ \\
\hline \multirow[t]{4}{*}{ testosterone } & & Weighted median & 1.47 (1.20 to 1.82$)$ & $2.46 \times 10^{-4}$ \\
\hline & & Weighted mode & 1.51 (1.19 to 1.93$)$ & $1.16 \times 10^{-3}$ \\
\hline & & MR Egger & 1.90 (1.46 to 2.47$)$ & $5.63 \times 10^{-6}$ \\
\hline & Endometrioid endometrial cancer & IVW & 1.46 (1.26 to 1.69$)$ & $3.08 \times 10^{-7}$ \\
\hline
\end{tabular}


medRxiv preprint doi: https://doi.org/10.1101/2021.12.10.21267599; this version posted December 13, 2021. The copyright holder for this preprint (which was not certified by peer review) is the author/funder, who has granted medRxiv a license to display the preprint in perpetuity.

It is made available under a CC-BY-NC-ND 4.0 International license .

\begin{tabular}{|c|c|c|c|c|}
\hline & & Weighted median & $1.42(1.14$ to 1.76$)$ & $1.97 \times 10^{-3}$ \\
\hline & & Weighted mode & 1.60 (1.20 to 2.13$)$ & $1.59 \times 10^{-3}$ \\
\hline & & MR Egger & 1.79 (1.31 to 2.43$)$ & $3.08 \times 10^{-7}$ \\
\hline \multirow[t]{8}{*}{ SHBG } & Overall endometrial cancer & IVW & 0.71 (0.59 to 0.85$)$ & $2.07 \times 10^{-4}$ \\
\hline & & Weighted median & $0.64(0.48$ to 0.86$)$ & $2.54 \times 10^{-3}$ \\
\hline & & Weighted mode & 0.69 (0.53 to 0.89$)$ & $4.97 \times 10^{-3}$ \\
\hline & & MR Egger & $0.62(0.46$ to 0.84$)$ & $2.52 \times 10^{-3}$ \\
\hline & Endometrioid endometrial cancer & IVW & $0.65(0.54$ to 0.80$)$ & $3.31 \times 10^{-5}$ \\
\hline & & Weighted median & $0.60(0.43$ to 0.86$)$ & $4.90 \times 10^{-3}$ \\
\hline & & Weighted mode & $0.58(0.40$ to 0.82$)$ & $2.50 \times 10^{-3}$ \\
\hline & & MR Egger & 0.61 (0.44 to 0.84$)$ & $3.33 \times 10^{-3}$ \\
\hline
\end{tabular}

1080

1081

1082

1083

1084

1085

1086

1087

1088

1089
ORs are shown per increase in inverse normal transformed nmol/L SHBG, natural log transformed $\mathrm{pmol} / \mathrm{L}$ fasting insulin, inverse normal transformed nmol/L total testosterone, inverse normal transformed nmol/L bioavailable testosterone, SD (38.7 mg/dL) LDL-cholesterol, nmol/L IGF-1, mmol/L blood glucose, natural log transformed CRP mg/L IL-6, natural log transformed ug/ml adiponectin for combined instrument, natural log transformed ug/ml cis-only adiponectin, natural log transformed $\mathrm{mg} / \mathrm{L}$ $\mathrm{CRP}, \mathrm{mg} / \mathrm{dL}$ triglyceride, $\mathrm{SD}(41.7 \mathrm{mg} / \mathrm{dL})$ total serum cholesterol, $\mathrm{mg} / \mathrm{dL}$ HDL-cholesterol, $\mathrm{pg} / \mathrm{mL}$ leptin . LDL = low-density lipoprotein, HDL = high density lipoprotein, IGF-1 = Insulin-like growth factor-1, IL-6 = interleukin-6, CRP = C-reactive protein, SHBG = sex hormone-binding globulin, IVW = inverse-variance weighted. For instrument construction of IGF-1 (cis and trans variants), a $P$ value of $5 \times 10^{-6}$ was used. 
medRxiv preprint doi: https://doi.org/10.1101/2021.12.10.21267599; this version posted December 13, 2021. The copyright holder for this preprint (which was not certified by peer review) is the author/funder, who has granted medRxiv a license to display the preprint in perpetuity.

It is made available under a CC-BY-NC-ND 4.0 International license .

1090 Table 4. Results of MR analyses examining the effect of BMI on previously reported molecular risk 1091 factors.

\begin{tabular}{|c|c|c|c|}
\hline Outcome & Method & Effect estimate $(95 \% \mathrm{Cl})$ & $P$ value \\
\hline \multirow[t]{4}{*}{ Total serum cholesterol } & IVW & $-0.03(-0.06$ to 0.01$)$ & $1.22 \times 10^{-1}$ \\
\hline & Weighted median & $-0.06(-0.11$ to -0.01$)$ & $2.98 \times 10^{-2}$ \\
\hline & Weighted mode & $-0.08(-0.15$ to 0.00$)$ & $4.46 \times 10^{-2}$ \\
\hline & MR Egger & $-0.08(-0.16$ to 0.00$)$ & $3.89 \times 10^{-2}$ \\
\hline \multirow[t]{4}{*}{ Fasting insulin } & IVW & 0.17 (0.15 to 0.19$)$ & $1.51 \times 10^{-74}$ \\
\hline & Weighted median & $0.18(0.15$ to 0.21$)$ & $8.51 \times 10^{-31}$ \\
\hline & Weighted mode & $0.18(0.12$ to 0.24$)$ & $1.88 \times 10^{-9}$ \\
\hline & MR Egger & $0.20(0.16$ to 0.25$)$ & $1.30 \times 10^{-16}$ \\
\hline \multirow[t]{4}{*}{ Total testosterone } & IVW & $0.08(0.05$ to 0.11$)$ & $9.04 \times 10^{-10}$ \\
\hline & Weighted median & 0.06 (0.03 to 0.09$)$ & $4.95 \times 10^{-4}$ \\
\hline & Weighted mode & $-0.01(-0.08$ to 0.07$)$ & $8.60 \times 10^{-1}$ \\
\hline & MR Egger & 0.02 (-0.05 to 0.09$)$ & $5.23 \times 10^{-1}$ \\
\hline \multirow[t]{4}{*}{ Bioavailable testosterone } & IVW & $0.26(0.23$ to 0.29$)$ & $9.97 \times 10^{-68}$ \\
\hline & Weighted median & $0.24(0.20$ to 0.28$)$ & $1.72 \times 10^{-38}$ \\
\hline & Weighted mode & 0.09 (0.01 to 0.17$)$ & $2.41 \times 10^{-2}$ \\
\hline & MR Egger & $0.16(0.08$ to 0.24$)$ & $4.36 \times 10^{-5}$ \\
\hline \multirow[t]{4}{*}{ SHBG } & IVW & $-0.17(-0.19$ to -0.16$)$ & $4.86 \times 10^{-125}$ \\
\hline & Weighted median & $-0.16(-0.18$ to -0.15$)$ & $8.85 \times 10^{-77}$ \\
\hline & Weighted mode & $-0.15(-0.18$ to -0.12$)$ & $8.43 \times 10^{-20}$ \\
\hline & MR Egger & $-0.13(-0.17$ to -0.09$)$ & $3.11 \times 10^{-11}$ \\
\hline
\end{tabular}


medRxiv preprint doi: https://doi.org/10.1101/2021.12.10.21267599; this version posted December 13, 2021. The copyright holder for this preprint (which was not certified by peer review) is the author/funder, who has granted medRxiv a license to display the preprint in perpetuity. It is made available under a CC-BY-NC-ND 4.0 International license .

$1092 \mathrm{BMI}$ is scaled to an SD increase $\left(4.7 \mathrm{~kg} / \mathrm{m}^{2}\right)$. Effect estimate represents change in SD $(41.7 \mathrm{mg} / \mathrm{dL})$ total 1093 serum cholesterol, natural log transformed pmol/L fasting insulin, inverse normal transformed nmol/L 1094 total testosterone, inverse normal transformed $\mathrm{nmol} / \mathrm{L}$ bioavailable testosterone, and inverse normal 1095 transformed nmol/L SHBG. SHBG = sex hormone-binding globulin, IVW = inverse-variance weighted. 
medRxiv preprint doi: https://doi.org/10.1101/2021.12.10.21267599; this version posted December 13, 2021. The copyright holder for this preprint (which was not certified by peer review) is the author/funder, who has granted medRxiv a license to display the preprint in perpetuity.

It is made available under a CC-BY-NC-ND 4.0 International license .

1096 Table 5. Results of multivariable MR mediation analysis examining the effect of BMI and endometrial

1097 cancer with previously reported molecular risk factors as potential mediators.

$\begin{array}{ccccc} & & \text { Indirect Effect of } & \% \text { Mediated } \\ \text { Mediator } & \text { Direct Effect of } & \text { Mediator on } & (95 \% \mathrm{Cl}) & P \text { value }\end{array}$

\begin{tabular}{|c|c|c|c|c|c|}
\hline Fasting & Overall & 1.75 & 1.07 & $11 \%$ (1 to $21 \%)$ & $2.89 \times 10^{-2}$ \\
\hline \multirow[t]{3}{*}{ insulin } & Endometrial Cancer & & & & \\
\hline & Endometrioid & 1.72 & 1.11 & $16 \%$ (3 to $28 \%$ ) & $1.24 \times 10^{-2}$ \\
\hline & Endometrial Cancer & & & & \\
\hline Bioavailable & Overall & 1.70 & 1.11 & $15 \%$ (10 to $20 \%$ ) & $1.43 \times 10^{-8}$ \\
\hline \multirow[t]{3}{*}{ testosterone } & Endometrial Cancer & & & & \\
\hline & Endometrioid & 1.72 & 1.11 & $15 \%$ (9 to $22 \%)$ & $2.15 \times 10^{-6}$ \\
\hline & Endometrial Cancer & & & & \\
\hline \multirow[t]{4}{*}{ SHBG } & Overall & 1.80 & 1.04 & $7 \%$ (1 to $12 \%)$ & $1.81 \times 10^{-2}$ \\
\hline & Endometrial Cancer & & & & \\
\hline & Endometrioid & 1.86 & 1.02 & $2 \%(-9$ to $14 \%)$ & $6.87 \times 10^{-1}$ \\
\hline & Endometrial Cancer & & & & \\
\hline \multicolumn{6}{|c|}{ Direct effect is defined as the remaining effect of the exposure (BMI) on the outcome (endometrial } \\
\hline \multicolumn{6}{|c|}{ cancer risk) when the effect of the candidate mediator on the outcome has been adjusted for. Indirect } \\
\hline \multicolumn{6}{|c|}{ effect is defined as the effect of the exposure (BMI) on the outcome (endometrial cancer risk) through } \\
\hline
\end{tabular}


1102

1103

1104

1105

1106

1107

1108

1109

1110

1111

\section{Supporting Information Captions}

S1 Appendix. List of unique molecular traits identified from literature search.

S2 Appendix. Supplementary methods.

S3 Appendix. PubMed search terms for literature review.

S4 Table. Additional information on GWAS, including covariates adjusted for.

S5 Table. Sample overlap between GWAS.

S6 Table. Conditional F-statistics for multivariable Mendelian randomization of BMI and mediators on endometrial cancer risk.

S7 Figure. Leave-one-out analysis for MR examining the effect of adult BMI on overall endometrial cancer risk.

S8 Table. Results of female BMI sensitivity analysis MR.

S9 Table. Results from sensitivity analyses examining the influence of Winner's curse on GWAS with overlapping samples.

S10 Figure. Leave-one-out analysis for MR examining the effect of adult BMI on endometrioid endometrial cancer risk.

S11 Figure. Leave-one-out analysis for MR examining the effect of adult BMI on non-endometrioid endometrial cancer risk.

S12 Figure. Leave-one-out analysis for MR examining the effect of total testosterone level on endometrial cancer risk. 
1121

1122

1123

1124

S13 Figure. Leave-one-out analysis for MR examining the effect of bioavailable testosterone level on endometrial cancer risk.

S14 Figure. Leave-one-out analysis for MR examining the effect of fasting insulin level on endometrial cancer risk.

S15 Figure. Leave-one-out analysis for MR examining the effect of SHBG level on endometrial cancer risk.

S16 Figure. Leave-one-out analysis for MR examining the effect of total serum cholesterol level on endometrial cancer risk.

S17 Table. Results of female-specific SNP fasting insulin sensitivity analysis MR.

S18 Table. Results of female-specific SNP CRP sensitivity analysis MR.

S19 Figure. Leave-one-out analysis for MR examining the effect of total testosterone level on endometrioid endometrial cancer risk.

S20 Figure. Leave-one-out analysis for MR examining the effect of bioavailable testosterone level on endometrioid endometrial cancer risk.

S21 Figure. Leave-one-out analysis for MR examining the effect of fasting insulin level on endometrioid endometrial cancer risk.

S22 Figure. Leave-one-out analysis for MR examining the effect of SHBG level on endometrioid endometrial cancer risk.

S23 Figure. Leave-one-out analysis for MR examining the effect of adult BMI on fasting insulin level. 
medRxiv preprint doi: https://doi.org/10.1101/2021.12.10.21267599; this version posted December 13, 2021. The copyright holder for this preprint (which was not certified by peer review) is the author/funder, who has granted medRxiv a license to display the preprint in perpetuity.

It is made available under a CC-BY-NC-ND 4.0 International license .

S24 Figure. Leave-one-out analysis for MR examining the effect of adult BMI on SHBG level.

S25 Figure. Leave-one-out analysis for MR examining the effect of adult BMI on bioavailable testosterone level.

S26 Figure. Leave-one-out analysis for MR examining the effect of adult BMI on total serum cholesterol level.

S27 Figure. Leave-one-out analysis for MR examining the effect of adult BMI on C-reactive protein level.

S28 Table. Results of female-specific SNP BMI sensitivity mediation analysis.

S29 Table. Results of female-specific SNP fasting insulin mediation analysis.

S30 Table. Results of multivariable MR mediation analysis examining the effect of BMI and endometrial cancer with fasting insulin as a potential mediator with BMI-adjusted fasting insulin instrument and 100 SNPs from BMI instrument.

S31 Table. Results from sensitivity analyses examining the influence of Winner's curse on GWAS with overlapping samples in analyses determining the mediating role of traits in the relationship between BMI and endometrial cancer risk.

S32 Table. Results from sensitivity analyses examining the influence of Winner's curse on GWAS with overlapping samples in analyses determining the interdependent effects of mediators of the relationship between BMI and endometrial cancer risk.

S33 Table. Conditional F-statistics for further multivariable Mendelian randomization analyses.

S34 Table. Results of multivariable MR mediation analysis examining the effect of endometrial cancer with pairs of confirmed mediating molecular traits without BMI. 
medRxiv preprint doi: https://doi.org/10.1101/2021.12.10.21267599; this version posted December 13, 2021. The copyright holder for this preprint (which was not certified by peer review) is the author/funder, who has granted medRxiv a license to display the preprint in perpetuity.

It is made available under a CC-BY-NC-ND 4.0 International license .

1161

1162

1163

1164

1165

1166

1167

S35 Table. Results of multivariable MR mediation analysis examining the effect of BMI and endometrial cancer with fasting insulin as a potential mediator with 100 SNPs from BMI instrument.

S36 Table. Results of multivariable MR mediation analysis examining the effect of BMI and endometrial cancer with fasting insulin as a potential mediator with BMI-adjusted fasting insulin instrument.

S37 Table. Conditional F-statistics for fasting insulin (adjusted for BMI) and BMI with differing thresholds used to construct fasting insulin.

S38 Table. Results of multivariable MR mediation analysis examining the effect of BMI and endometrial cancer with all confirmed mediating molecular traits with BMI-adjusted fasting insulin.

S39 Table. Results of multivariable MR mediation analysis examining the effect of BMI and endometrial cancer with pairs of confirmed mediating molecular traits.

S40 Table. Results of multivariable MR mediation analysis examining the effect of BMI and endometrial cancer with all confirmed mediating molecular traits including fasting insulin adjusted for BMI with 100 SNPs from BMI instrument.

S41 Table. Results of multivariable MR mediation analysis examining the effect of BMI and endometrial cancer with pairs of confirmed mediating molecular traits with 100 SNPs from BMI instrument.

S42 Table. Results of multivariable MR mediation analysis examining the effect of endometrial cancer with all confirmed mediating molecular traits without BMI.

S43 Table. Results of sensitivity analysis examining the effect of only including 100 SNPs for the BMI instrument in MR analyses. 
medRxiv preprint doi: https://doi.org/10.1101/2021.12.10.21267599; this version posted December 13, 2021. The copyright holder for this preprint (which was not certified by peer review) is the author/funder, who has granted medRxiv a license to display the preprint in perpetuity. It is made available under a CC-BY-NC-ND 4.0 International license .

1182 S44 Table. Conditional F-statistics with different levels of genetic correlation for SHBG and BMI in multivariable Mendelian randomization analyses.

1184 S45 Table. Results of HEIDI test-filtered low-density lipoprotein (LDL) cholesterol and overall 1185 endometrial cancer MR. 
20 risk factors identified from two PubMed literature searches

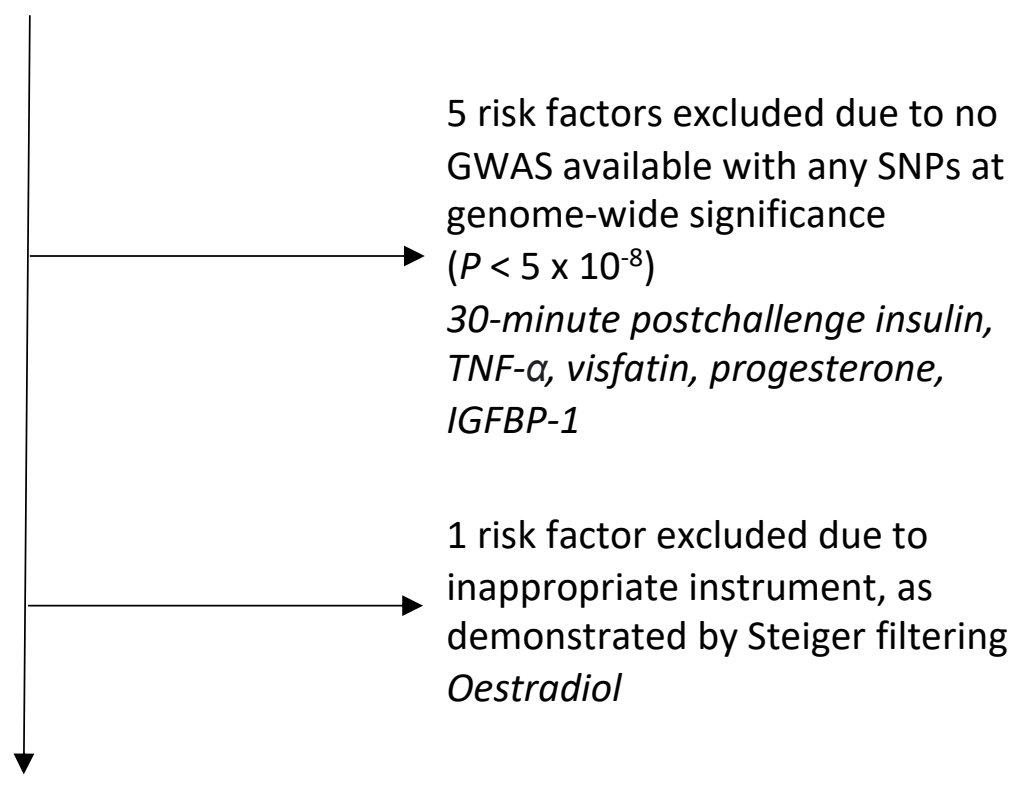

14 risk factors investigated in

MR analyses

LDL-cholesterol, HDL-cholesterol,

triglyceride, total serum

cholesterol, glucose, fasting

insulin, IGF-1, IL-6, adiponectin,

leptin, $C R P$, total testosterone,

bioavailable testosterone, SHBG

Fig 1. 
medRxiv preprint doi: https://doi.org/10.1101/2021.12.10.21267599; this version posted December 13, 2021. The copyright holder for this preprint (which was not certified by peer review) is the author/funder, who has granted medRxiv a license to display the preprint in perpetuity.

It is made available under a CC-BY-NC-ND 4.0 International license .

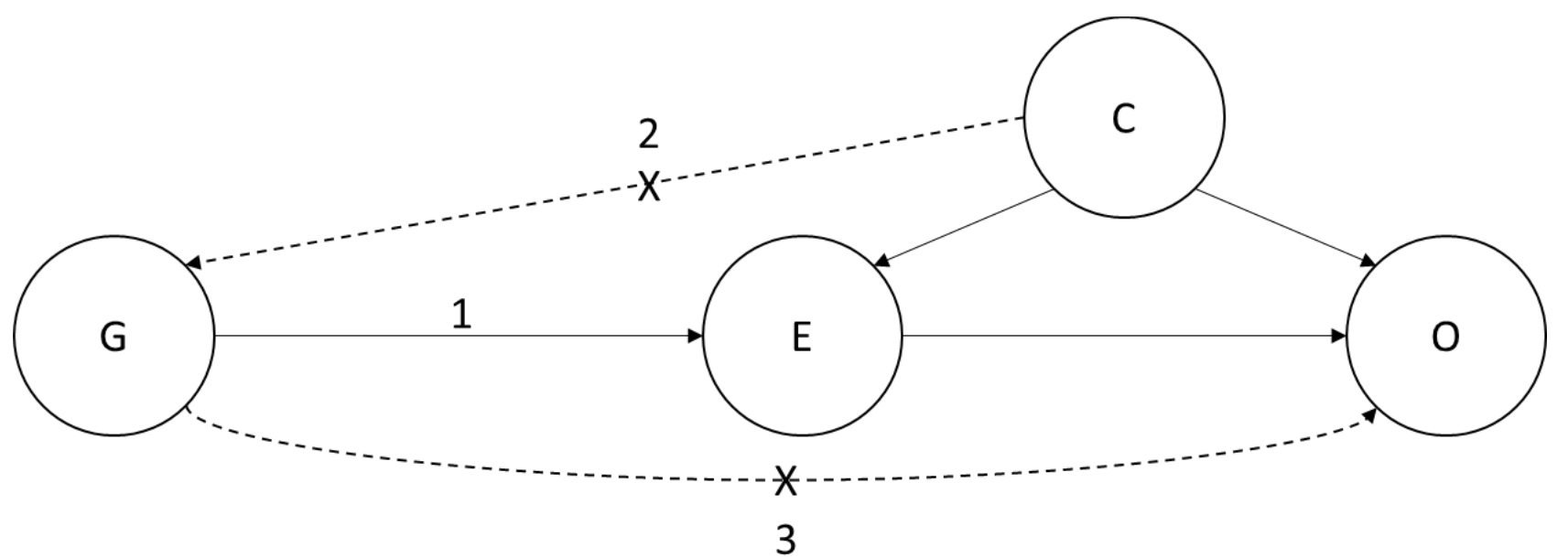

Fig 2. 
medRxiv preprint doi: https://doi.org/10.1101/2021.12.10.21267599; this version posted December 13, 2021. The copyright holder for this preprint (which was not certified by peer review) is the author/funder, who has granted medRxiv a license to display the preprint in perpetuity.

It is made available under a CC-BY-NC-ND 4.0 International license .

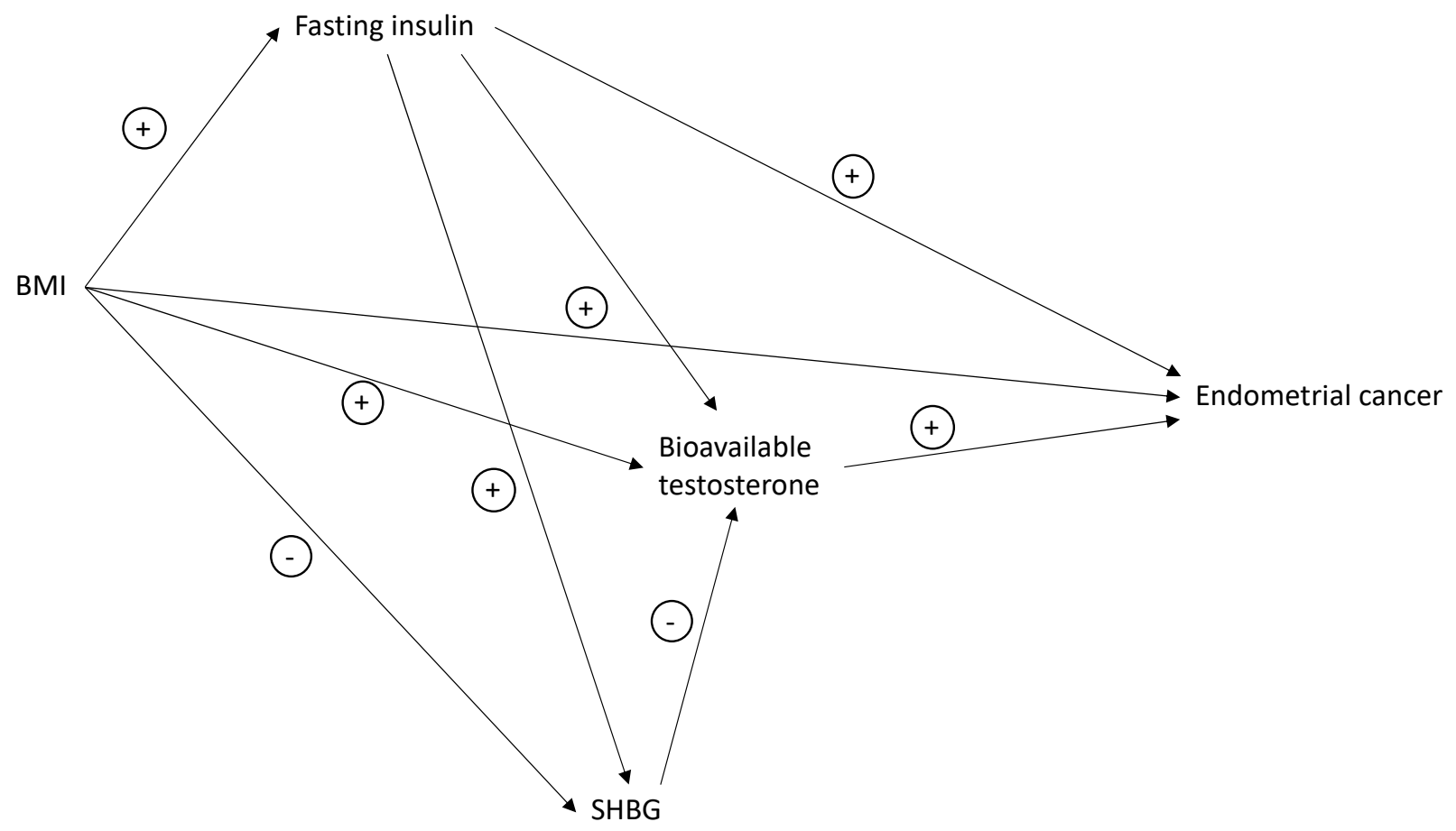

Fig 3. 
medRxiv preprint doi: https://doi.org/10.1101/2021.12.10.21267599; this version posted December 13, 2021. The copyright holder for this preprint (which was not certified by peer review) is the author/funder, who has granted medRxiv a license to display the preprint in perpetuity.

It is made available under a CC-BY-NC-ND 4.0 International license .

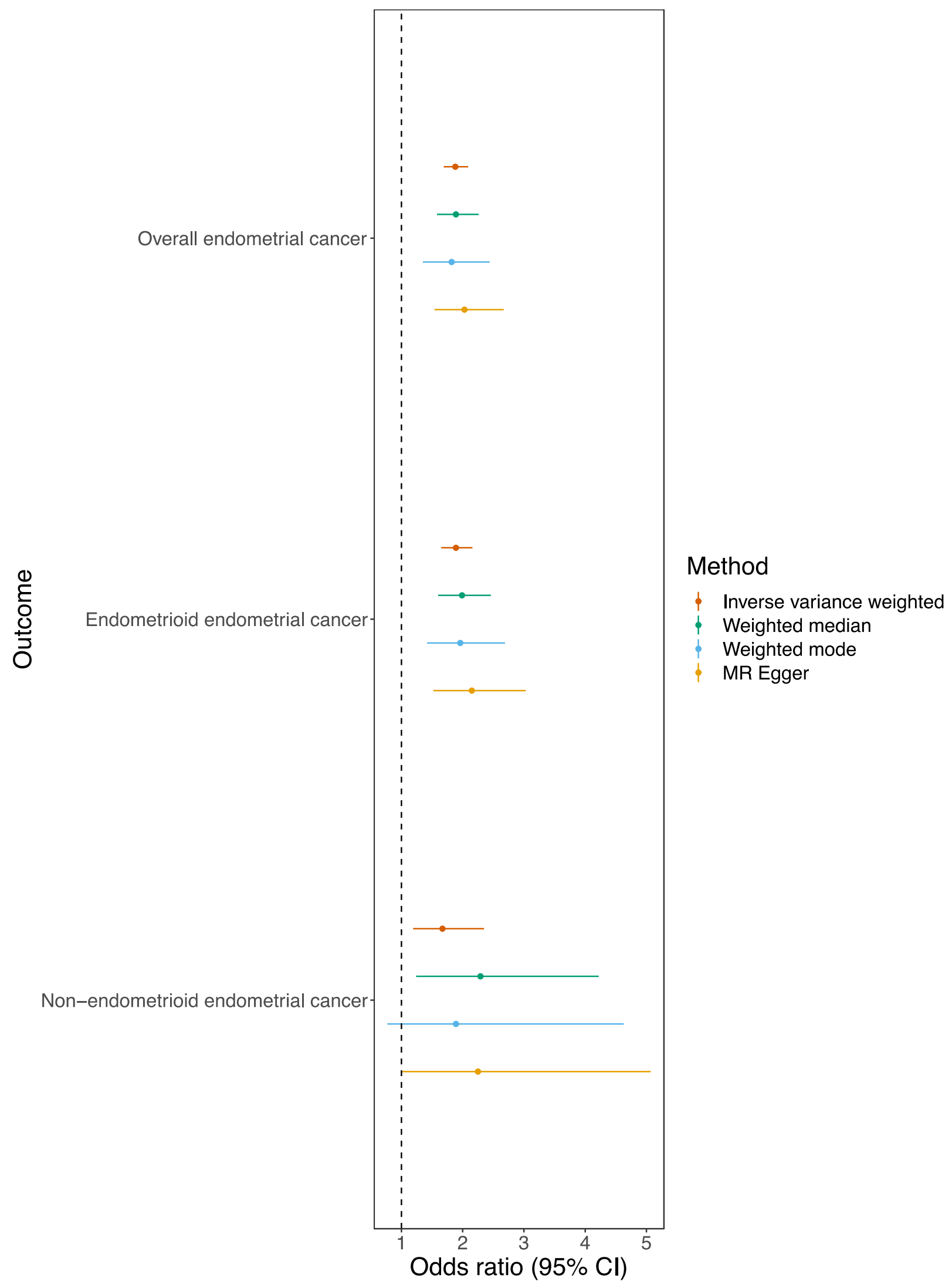

Fig 4. 
medRxiv preprint doi: https://doi.org/10.1101/2021.12.10.21267599; this version posted December 13, 2021. The copyright holder for this preprint (which was not certified by peer review) is the author/funder, who has granted medRxiv a license to display the preprint in perpetuity.

It is made available under a CC-BY-NC-ND 4.0 International license .

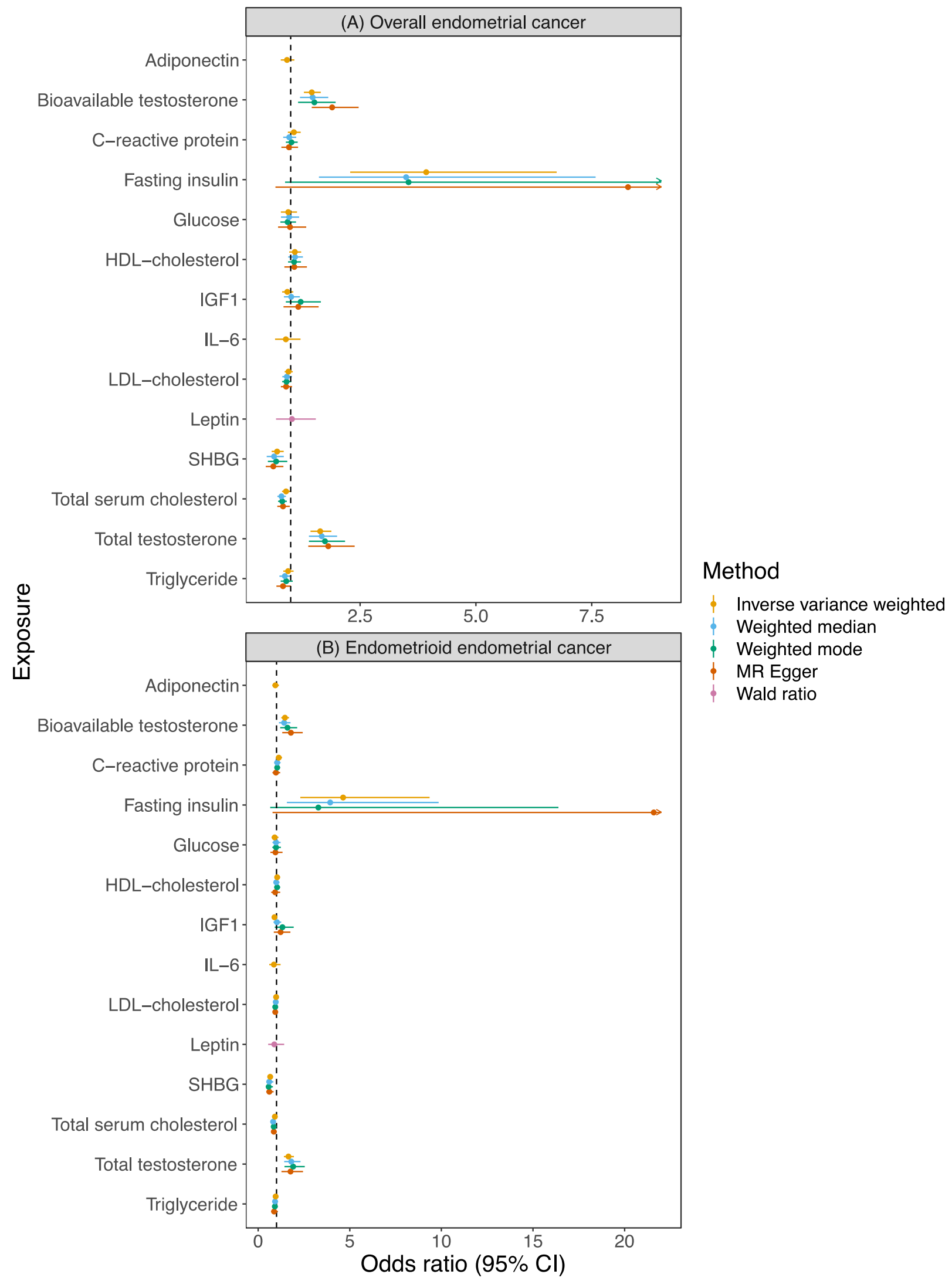

Fig 5. 
medRxiv preprint doi: https://doi.org/10.1101/2021.12.10.21267599; this version posted December 13, 2021. The copyright holder for this preprint (which was not certified by peer review) is the author/funder, who has granted medRxiv a license to display the preprint in perpetuity.

It is made available under a CC-BY-NC-ND 4.0 International license .

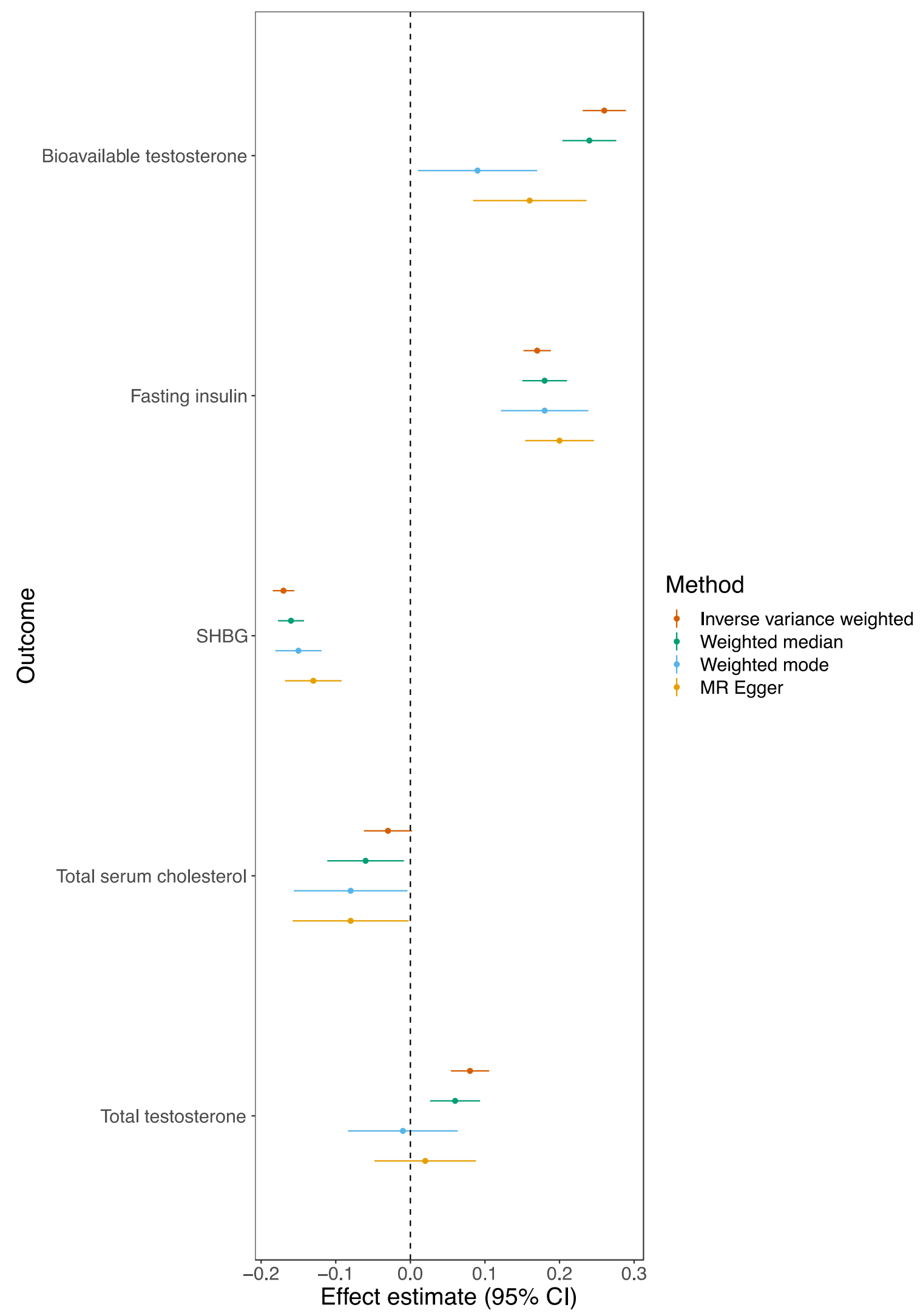

Fig 6. 